Article

\title{
Mixed Metal Oxide Systems Applied to Thermochemical Storage of Solar Energy: Benefits of Secondary Metal Addition in Co and Mn Oxides and Contribution of Thermodynamics
}

\author{
Laurie André ${ }^{1}$, Stéphane Abanades ${ }^{1, *(D)}$ and Laurent Cassayre ${ }^{2}$ (D) \\ 1 Processes, Materials, and Solar Energy Laboratory, PROMES-CNRS, 7 Rue du Four Solaire, \\ 66120 Font-Romeu, France; laurie.andre@promes.cnrs.fr \\ 2 Laboratoire de Génie Chimique, Université de Toulouse, CNRS, Toulouse, France; \\ laurent.cassayre@ensiacet.fr \\ * Correspondence: stephane.abanades@promes.cnrs.fr; Tel.: +33-4-68-30-77-30
}

Received: 19 October 2018; Accepted: 8 December 2018; Published: 14 December 2018 updates

\begin{abstract}
Thermochemical energy storage is promising for the long-term storage of solar energy via chemical bonds using reversible redox reactions. The development of thermally-stable and redox-active materials is needed, as single metal oxides (mainly Co and Mn oxides) show important shortcomings that may delay their large-scale implementation in solar power plants. Drawbacks associated with Co oxide concern chiefly cost and toxicity issues while Mn oxide suffers from slow oxidation kinetics and poor reversibility. Mixed metal oxide systems could alleviate the above-mentioned issues, thereby achieving improved materials characteristics. All binary oxide mixtures of the $\mathrm{Mn}-\mathrm{Co}-\mathrm{Fe}-\mathrm{Cu}-\mathrm{O}$ system are considered in this study, and their properties are evaluated by experimental measurements and/or thermodynamic calculations. The addition of $\mathrm{Fe}, \mathrm{Cu}$ or $\mathrm{Mn}$ to cobalt oxide decreased both the oxygen storage capacity and energy storage density, thus adversely affecting the performance of $\mathrm{Co}_{3} \mathrm{O}_{4} / \mathrm{CoO}$. Conversely, the addition of $\mathrm{Fe}, \mathrm{Co}$ or $\mathrm{Cu}$ (with added amounts above 15, 40 and $30 \mathrm{~mol} \%$, respectively) improved the reversibility, re-oxidation rate and energy storage capacity of manganese oxide. Computational thermodynamics was applied to unravel the governing mechanisms and phase transitions responsible for the materials behavior, which represents a powerful tool for predicting the suitability of mixed oxide systems applied to thermochemical energy storage.
\end{abstract}

Keywords: concentrated solar energy; solar power; thermochemical energy storage; mixed metal oxide; redox reaction; computational thermodynamics

\section{Introduction}

The intermittent nature of solar energy used to drive concentrated solar power (CSP) plants calls for a suitable energy storage system, which will grant us the freedom to produce and dispatch electricity according to the population needs. Thermal energy storage (TES) can serve this purpose to match the variable electricity demand with the intermittent energy source supply, and much progress has been achieved with latent heat and sensible heat storage systems already in use in CSP plants [1-4]. Alongside these conventional modes of heat storage, thermochemical energy storage (TCES) is an attractive option to store solar energy at higher temperatures $\left(400-1200^{\circ} \mathrm{C}\right)$ and to be compatible with next generation CSP plants, such as pressurized air-based solar tower receivers for power generation via gas turbines. These high-temperature processes associated with thermodynamic power cycles will enable higher solar to electricity conversion efficiency. TCES offers higher energy storage densities and 
possible heat storage at room temperature in the form of stable solid materials, due to energy storage in the form of chemical bonds, which then relates to long-term/seasonal storage. Its main application goal is still related to day/night operation of the power block in a CSP plant for continuous electricity generation. This technology is based on reversible solid-gas reactions, in which the heat transfer fluid is also the reactive gas of the reaction, and the energy required for the endothermic reaction is provided by CSP (Equation (1)). The reverse reaction (exothermic) can then release the stored energy to be delivered to the heat transfer fluid.

$$
\mathrm{AB}(\mathrm{s})+\text { Heat }(\mathrm{CSP}) \leftrightharpoons \mathrm{A}(\mathrm{s})+\mathrm{B}(\mathrm{g})
$$

Active research is ongoing for the development of suitable TCES systems and for their commercial implementation. In this endeavor however, additional research and development is required to achieve long-term cost-effective systems as a suitable way to implement TCES in solar power plants [5]. Recently, Bayon et al. (2018) [6] reported an interesting economical evaluation of 17 potential systems for TCES implementation in solar power plants. As a few systems are known to hold suitable properties (reversibility, high energy storage density, availability at low cost and non-toxicity) for TCES application (such as $\mathrm{Ca}(\mathrm{OH})_{2} / \mathrm{CaO}, \mathrm{Sr}(\mathrm{OH})_{2} / \mathrm{SrO}$ and $\mathrm{Ba}(\mathrm{OH})_{2} / \mathrm{BaO}$; carbonate looping with $\mathrm{CaCO}_{3} / \mathrm{CaO}$ and $\mathrm{SrCO}_{3} / \mathrm{SrO}$; redox with $\mathrm{BaO}_{2} / \mathrm{BaO}$ ), their implementation would also be cost competitive with molten salts in the near term [6].

Various systems can be considered, other than metal oxides [3,7]. For example, hydroxides, and especially calcium hydroxide [8-14] shows promising results for TCES. The systems based on carbonates are also relevant for TCES application. Calcium [15-18] and strontium carbonate [18,19] systems are promising but still require structure stabilization to hinder sintering at high reaction temperatures. In the specific case of single metal oxides, air can be used as heat transfer fluid (Equations (2) and (3)), which allows operating with an open-loop system.

$$
\begin{aligned}
& \mathrm{MO}_{(\mathrm{ox})}+\text { Heat } \rightarrow \mathrm{MO}_{(\text {red })}+\alpha \mathrm{O}_{2}(\mathrm{~g}) \\
& \mathrm{MO}_{(\text {red })}+\alpha \mathrm{O}_{2}(\mathrm{~g}) \rightarrow \mathrm{MO}_{(\mathrm{ox})}+\text { Heat }
\end{aligned}
$$

In particular, $\mathrm{Co}_{3} \mathrm{O}_{4} / \mathrm{CoO}$ and $\mathrm{Mn}_{2} \mathrm{O}_{3} / \mathrm{Mn}_{3} \mathrm{O}_{4}$ are known to be the most promising redox systems, while $\mathrm{CuO} / \mathrm{Cu}_{2} \mathrm{O}$ also demonstrates suitable TCES properties [20-26].

The interest of $\mathrm{Co}_{3} \mathrm{O}_{4} / \mathrm{CoO}$ for TCES application comes from its fast reaction kinetics, complete reaction reversibility, high energy storage capacity and excellent cycling stability with a transition temperature suited for CSP application $\left(892^{\circ} \mathrm{C}\right.$, Table 1$)$, and with a measured gravimetric energy storage density of $576 \mathrm{~kJ} / \mathrm{kg}$ [27], while the theoretical reaction enthalpy is reported to be as high as $844 \mathrm{~kJ} / \mathrm{kg}$ [28-30]. It has been studied in various forms to be implemented within CSP reactors as an energy storage unit. A numerical model was developed by Singh et al. (2017) [31] to simulate the heat and mass transfer, and chemical reaction involving a cobalt-based material inside a thermochemical storage system. The numerical model was validated as it was compared to the experimental reaction of $\mathrm{Co}_{3} \mathrm{O}_{4} / \mathrm{CoO}$ coated on a cordierite honeycomb structure inside a prototype reactor. The model could accurately predict the performance of the storage reactor during the charge/discharge steps. The performance of cobalt oxide in different shapes, such as powders, foams, pellets and honeycomb structures made from the oxide or coated, was studied. For example, the use of small-scale honeycomb structures was considered by Karagiannakis et al. (2016) [32] and cobalt-based honeycomb structures were tested in air between $700{ }^{\circ} \mathrm{C}$ and $1000{ }^{\circ} \mathrm{C}$. The honeycomb made of pure $\mathrm{Co}_{3} \mathrm{O}_{4}$ suffered from deformation during redox cycling due to extensive swelling caused by $\mathrm{Co}_{3} \mathrm{O}_{4} / \mathrm{CoO}$ phase transitions. The addition of $10 \mathrm{wt} \% \mathrm{Al}_{2} \mathrm{O}_{3}$ to $\mathrm{Co}_{3} \mathrm{O}_{4}$, to form a honeycomb structure made of a $\mathrm{Co}_{3} \mathrm{O}_{4}-\mathrm{Al}_{2} \mathrm{O}_{3}$ composite, proved to efficiently restrain extensive swelling of $\mathrm{Co}_{3} \mathrm{O}_{4} / \mathrm{CoO}$ after several redox cycles, but decreased the material storage efficiency over time, due to the formation of cobalt aluminate. The performance of cobalt oxide-based foams and honeycomb structures was also studied in the range 
of 800-1000 ${ }^{\circ} \mathrm{C}$ and compared to $\mathrm{Co}_{3} \mathrm{O}_{4}$ powder [28]. The full reduction/oxidation of the total mass of $\mathrm{Co}_{3} \mathrm{O}_{4}$ coated on the supports $\left(\mathrm{Al}_{2} \mathrm{O}_{3}, \mathrm{ZrO}_{2}\right.$ and cordierite) was observed, as opposed to $\mathrm{Co}_{3} \mathrm{O}_{4}$ on $\mathrm{SiC}$ supports. Moreover, no detrimental interaction between the cobalt oxide and the support, such as $\mathrm{Al}_{2} \mathrm{O}_{3}, \mathrm{ZrO}_{2}$ and cordierite, was reported. Furthermore, the protection of $\mathrm{SiC}$ with a $\mathrm{SiO}_{2}$ layer also proved to offer a full conversion of the material.

Flow-through pellets, perforated monolithic bodies of $\mathrm{Co}_{3} \mathrm{O}_{4}$, or composites of $\mathrm{Co}_{3} \mathrm{O}_{4}$ with ceria, zirconia, alumina, iron oxide, silicon carbide and manganese oxide, were investigated by Pagkoura et al. (2014) [33] for energy storage applications in CSP plants. Based on their good heat storage capacity and thermo-mechanical stability, both cobalt oxide-alumina and cobalt oxide-iron oxide were considered very promising in this study. On the other hand, the addition of ceria ( $25 \mathrm{wt} \%)$ enhanced the reaction kinetics of cobalt oxide, while the corresponding pellets exhibited poor thermo-mechanical stability. A change in the temperature for the beginning of the reduction/oxidation reaction was also observed with a modification in the added second oxide.

The performance of commercial $\mathrm{Co}_{3} \mathrm{O}_{4}$ powder in a fixed bed with air flow was appraised in a vertical quartz tube heated between $765{ }^{\circ} \mathrm{C}$ and $930{ }^{\circ} \mathrm{C}$ : full conversion and very good cycling stability over eight successive cycles were observed. A comparable study was conducted with commercial $\mathrm{Co}_{3} \mathrm{O}_{4}$ shaped into porous foams placed within a ceramic tube heated by a horizontal furnace. Full conversion and good cyclability were again obtained. The material shaping neither affected the reactivity, nor the $\mathrm{Co}_{3} \mathrm{O}_{4}$ stability [34].

Nonetheless, cobalt oxide is a potentially carcinogenic material and is expensive [6], which gives incentives for the development of other alternative materials. The manganese oxide system $\left(\mathrm{Mn}_{2} \mathrm{O}_{3} / \mathrm{Mn}_{3} \mathrm{O}_{4}\right)$ features slow kinetics of the oxidation step, which impacts the cycling reversibility of this material and requires performance improvement, but it is a less expensive raw material than cobalt oxide [35-37]. This system can achieve a gravimetric energy storage density of 110 to $160 \mathrm{~kJ} / \mathrm{kg}[37,38]$ and the theoretical reaction enthalpy is reported to be $202 \mathrm{~kJ} / \mathrm{kg}$ [37]. While $\mathrm{Co}_{3} \mathrm{O}_{4} / \mathrm{CoO}$ performs redox cycles with rapid reaction kinetics, $\mathrm{Mn}_{3} \mathrm{O}_{4}$ is very slow to re-oxidize and also presents a larger hysteresis than cobalt oxide [35-38]. Thus, the redox properties of $\mathrm{Mn}_{2} \mathrm{O}_{3} / \mathrm{Mn}_{3} \mathrm{O}_{4}$ need to be improved further to use this material efficiently for TCES application. A few works investigated the improvement of $\mathrm{Mn}_{3} \mathrm{O}_{4}$ re-oxidation kinetics via a change in morphology and shape of the initial material. The impact of the initial particle size on the cyclability of manganese oxide was studied [39], as well as the influence of the morphology and shape on the redox kinetics of the material [38,39]. The initial particle size influences the redox behavior of the metal oxide as smaller particles are more prone to material sintering and densification, which then hinders $\mathrm{O}_{2}$ diffusion to the reacting core, then affecting the re-oxidation step [39,40]. In addition to the influence of initial particle size on the reaction kinetics, a sintering issue can also be encountered especially for smaller particles that favor material sintering [39]. Due to this fact, the material re-oxidation can be observed in two steps, first during the temperature cooling down of the discharge step, then continuing during the next heating up of the following charging step, although the re-oxidation is sometimes not observed at all $[7,38,39]$. The performance of $\mathrm{Mn}_{2} \mathrm{O}_{3}$ powders resulting from different synthesis methods (modified Pechini method and precipitation in ammonia $[7,34]$ ) was compared, along with data from commercial powder. The material synthesized by Pechini and commercial powder showed very low re-oxidation, while the reduced powder from the synthesis by precipitation in ammonia was re-oxidized up to $93 \%$. Both synthetic powders were subjected to sintering, however the latter formed a porous structure described as "coral-like" [39] which allowed for oxygen circulating within the material.

As for the copper oxide $\left(\mathrm{CuO} / \mathrm{Cu}_{2} \mathrm{O}\right)$, it has been studied for air separation applications [23], but has also attracted attention for TCES application as it presents high energy storage capacity, $811 \mathrm{~kJ} / \mathrm{kg}[21,25]$ and the reaction temperature is suitable to be used with CSP [21,22,25]. However, the melting point of copper oxide is very close to the transition temperature and sintering issues are increased, which is not convenient to achieve a good cycling stability [25]. The onset temperature for the reduction of copper oxide was measured around $1028{ }^{\circ} \mathrm{C}$ under $20 \% \mathrm{O}_{2} / \mathrm{Ar}$ (Table 1) during the 
sample heating up [7]. The onset temperature measured for the re-oxidation during the next cooling down step was around $1002^{\circ} \mathrm{C}$. The material showed a good reversibility, however not total, with a maximum conversion of $88 \%$ observed with temperature kept constant at $950{ }^{\circ} \mathrm{C}$. In another TGA study in air, a re-oxidation of $92 \%$ for one cycle has been observed [23], with reduction and oxidation temperatures at $1075{ }^{\circ} \mathrm{C}$ and $1000{ }^{\circ} \mathrm{C}$, respectively. The suitability of $\mathrm{CuO} / \mathrm{Cu}_{2} \mathrm{O}$ for TCES was also tested in a rotary kiln reactor [21], in which the material suffered from sintering and thus to loss in capacity, with incomplete reduction ( $80 \%$ in $\mathrm{Ar}, 40 \%$ in air) and low re-oxidation ( $\sim 9 \%)$.

Lastly, the $\mathrm{Fe}_{2} \mathrm{O}_{3} / \mathrm{Fe}_{3} \mathrm{O}_{4}$ redox pair may also be a very attractive material for its low price and high availability. The $\mathrm{Fe}_{2} \mathrm{O}_{3} / \mathrm{Fe}_{3} \mathrm{O}_{4}$ redox pair also presents a high reaction enthalpy but the transition in air occurs at very high temperature $\left(1392{ }^{\circ} \mathrm{C}\right.$ [41]). The development of an efficient and suitable material for TCES application by incorporating iron oxide would help obtaining a more cost-effective energy storage medium with enhanced properties [6]. The reduction of $\mathrm{Fe}_{2} \mathrm{O}_{3}$ to $\mathrm{Fe}_{3} \mathrm{O}_{4}$ was observed under $20 \% \mathrm{O}_{2}$ atmosphere around $1391^{\circ} \mathrm{C}$ (Table 1), and reduction at lower temperature can be achieved under inert atmosphere $\left(958^{\circ} \mathrm{C}\right.$ in $\left.\mathrm{Ar}\right) . \mathrm{Fe}_{3} \mathrm{O}_{4}$ was then capable to regain $92 \mathrm{wt} \%$ of the previously released oxygen. When studied in air, $\mathrm{Fe}_{3} \mathrm{O}_{4}$ could be re-oxidized up to $80 \%\left(750-900{ }^{\circ} \mathrm{C}\right.$ ), and a decrease in conversion rate was noticed and attributed to the formation of an oxidized impervious layer which became thicker with increasing temperature [42]. Iron-based materials offer high gravimetric energy storage density as iron is a widely available and cheap material. However, used as such, raw $\mathrm{Fe}_{2} \mathrm{O}_{3}$ is reduced at very high temperature and thus presents a high risk to encounter sintering.

Nowadays, the development of alternative TCES materials with suitable properties for long-term exploitation in CSP plants remains a challenge. Single-metal oxide systems can hardly compete with $\mathrm{Co}_{3} \mathrm{O}_{4} / \mathrm{CoO}$ in terms of energy storage density, reaction kinetics and cycling stability. It is possible to achieve better redox performance with a metal oxide by modifying its morphology (for example through tailored synthesis), or through the addition of a secondary transition metal. In previous works, this method has been applied to modify single metal oxides, chiefly $\mathrm{Co}_{3} \mathrm{O}_{4}$ and $\mathrm{Mn}_{2} \mathrm{O}_{3}$, and the impacts of this modification on the tuning of reaction kinetics, cycling stability and reaction temperature, were reported [34-36]. The present work aims to compare experimental assessment of mixed metal oxide systems based on $\mathrm{Co}_{3} \mathrm{O}_{4} / \mathrm{CoO}$ and $\mathrm{Mn}_{2} \mathrm{O}_{3} / \mathrm{Mn}_{3} \mathrm{O}_{4}$ through binary mixing between $\mathrm{Co}, \mathrm{Mn}, \mathrm{Fe}$ and $\mathrm{Cu}$ oxides to provide an overview of the most suitable systems and to propose perspectives for future development of oxide-based TCES technology. In addition, the contribution of thermodynamics is presented for the better understanding of the underlying mechanisms governing the redox chemistry of the binary oxide systems. It relies on existing phase diagrams and thermodynamic models of the ternary systems $\mathrm{M}-\mathrm{M}^{\prime}-\mathrm{O}$ in air (where $\mathrm{M}$ and $\mathrm{M}^{\prime}$ are two different metals from $\mathrm{Co}, \mathrm{Mn}$, Fe and $\mathrm{Cu}$ ).

\section{Materials and Methods}

The redox activity of the synthesized mixed metal oxides was analyzed through simultaneous thermogravimetric analysis and differential scanning calorimetry (TGA/DSC, Netzsch, Selb, Germany). The materials, in the form of fine powders, were transferred to a ceramic crucible for thermal analysis. They were then heated (at $\left.10{ }^{\circ} \mathrm{C} / \mathrm{min}\right)$, under $20 \% \mathrm{O}_{2} / \mathrm{Ar}\left(10 \mathrm{NmL} / \mathrm{min}\right.$ for $\mathrm{O}_{2}$ and $40 \mathrm{NmL} / \mathrm{min}$ for $\operatorname{Ar}$ ) or $\operatorname{Ar}(40 \mathrm{NmL} / \mathrm{min})$, to perform the reduction step (endothermal), also called the heat charging step. Afterwards, the cycle was completed by cooling down the temperature (at $10^{\circ} \mathrm{C} / \mathrm{min}$ ) and performing the heat discharging step through the material re-oxidation (exothermal) to its original stoichiometry (using the same $20 \% \mathrm{O}_{2} /$ Ar mixture), to confirm the reaction reversibility. The same procedure was then repeated in the next cycles (total of 3 cycles).

The oxygen storage capacity (OSC) of the material was measured, corresponding to the mass of oxygen lost and recovered during these two steps (in w $\%$ of the total mass of metal oxide). The onset temperature for both steps was measured using Netzsch Proteus software tool. A difference in temperature between the reduction and re-oxidation was observed due to kinetic limitations and was depicted by the presence of a hysteresis phenomenon. This gap in temperature gains from being reduced, as it will then require less sensible energy to perform charge/discharge cycles if the variation 
in temperature between the two steps is minimized. Thanks to the combined DSC, the heat flow absorbed and released by the sample was also recorded and quantified in $\mathrm{kJ} / \mathrm{kg}(\Delta \mathrm{H})$ via the linear integration of endothermic (charge) and exothermic (discharge) reaction peaks. Experimental data concerning oxygen storage capacity of redox materials, transition temperatures during redox process, and reaction enthalpies were averaged over the course of three successive reduction/oxidation cycles for each material.

The hereafter presented experimental data were obtained using metal oxides synthesized via a modified Pechini method [43] from the corresponding metal nitrates ( $>98 \%$ purity) mixed with citric acid and ethylene glycol ( $>99 \%$ purity) in aqueous solution. The solution was heated up until obtaining a viscous solution. The powders were then calcined in air at $200^{\circ} \mathrm{C}$ for $2 \mathrm{~h}$ and at $750{ }^{\circ} \mathrm{C}$ for $4 \mathrm{~h}$ in order to eliminate the organics and residues of the synthesis, and to stabilize the structure. Crystalline phases were analyzed, before and after cycling, with X-ray diffraction (XRD) using a PANanalytical XPert Pro diffractometer, Malvern Panalytical, UK ( $\mathrm{CuK} \alpha$ radiation, $\lambda=0.15418 \mathrm{~nm}$ ). Detailed synthesis method and specific properties analysis can be found in previous works $[35,36]$. Throughout the study, the amount of secondary metal $\left(\mathrm{M}^{\prime}\right)$ added to the main metal $(\mathrm{M})$ is referred to as $\mathrm{x}\left(\mathrm{M}^{\prime}\right)$ (content of $\mathrm{M}^{\prime}$ in molar fraction), corresponding to the molar ratio on metal basis, $n\left(M^{\prime}\right) /\left(\left(n(M)+n\left(M^{\prime}\right)\right)\right.$.

\section{Experimental Assessment of Mixed Metal Oxide Systems for TCES}

None of the test has led to a melting of any redox pairs in the single-metal oxide systems, and complete reduction was generally achieved. However, the re-oxidation rates were low for all compounds except cobalt oxide [7]. Since $\mathrm{Co}_{3} \mathrm{O}_{4} / \mathrm{CoO}$ and $\mathrm{Mn}_{2} \mathrm{O}_{3} / \mathrm{Mn}_{3} \mathrm{O}_{4}$ are the two most promising materials for TCES, the potential of $\mathrm{Co}$ and Mn-based mixed oxides was investigated through the addition of a secondary metal, for example with copper [36,41], iron [27,35,41,44], or with one another [36,45]. A summary of the experimental data obtained in the present work is provided in Table 1.

Table 1. Experimental data obtained for the investigated oxide systems (with $20 \% \mathrm{O}_{2}$ in $\mathrm{Ar}$ ), comprising onset temperatures, chemical conversions and reaction enthalpy $(\mathrm{B}=$ Bixbyite, $\mathrm{C}=\mathrm{Corundum}, \mathrm{S}=$ Spinel, $\mathrm{H}=$ Hausmannite, $\mathrm{M}=$ Monoxide, $\mathrm{D}=$ Delafossite).

\begin{tabular}{|c|c|c|c|c|c|c|c|c|c|}
\hline \multirow{2}{*}{\multicolumn{2}{|c|}{ TCES System }} & \multicolumn{2}{|c|}{ Onset Temperature $\left({ }^{\circ} \mathrm{C}\right)$} & \multirow{3}{*}{$\begin{array}{c}\begin{array}{c}\text { Temperature } \\
\text { Gap }\left({ }^{\circ} \mathrm{C}\right)\end{array} \\
66\end{array}$} & \multirow{3}{*}{$\begin{array}{c}\begin{array}{c}\text { Conversion } \\
(\%)\end{array} \\
95.6\end{array}$} & \multirow{3}{*}{$\begin{array}{c}\begin{array}{c}\text { Exp. Reaction } \\
\text { Enthalpy (kJ/kg) }\end{array} \\
597\end{array}$} & \multirow{2}{*}{\multicolumn{3}{|c|}{$\begin{array}{l}\text { Phase Transition \& } \\
\text { Redox Couple }\end{array}$}} \\
\hline & & \multirow{2}{*}{$\begin{array}{c}\text { Reduction } \\
909\end{array}$} & \multirow{2}{*}{$\begin{array}{c}\text { Oxidation } \\
843\end{array}$} & & & & & & \\
\hline \multicolumn{2}{|c|}{$\mathrm{Co}_{3} \mathrm{O}_{4} / \mathrm{CoO}$} & & & & & & $\begin{array}{c}S \\
C_{0}^{I I I}\end{array}$ & $\rightarrow$ & $\begin{array}{c}M \\
C^{I I}\end{array}$ \\
\hline \multicolumn{2}{|c|}{$\mathrm{Mn}_{2} \mathrm{O}_{3} / \mathrm{Mn}_{3} \mathrm{O}_{4}$} & 944 & 772 & 172 & 19.2 & 148 & $\underset{M n^{I I I}}{\boldsymbol{B}}$ & $\rightarrow$ & $\underset{M n^{I I}}{\boldsymbol{H}}$ \\
\hline \multicolumn{2}{|c|}{$\mathrm{CuO} / \mathrm{Cu}_{2} \mathrm{O}$} & 1028 & 1002 & 26 & 87.1 & 536 & $\begin{array}{l}\mathrm{CuO} \\
\mathrm{Cu} u^{I I}\end{array}$ & $\rightarrow$ & $\begin{array}{c}\mathrm{Cu}_{2} \mathrm{O} \\
\mathrm{Cu} u^{I}\end{array}$ \\
\hline \multicolumn{2}{|c|}{$\mathrm{Fe}_{2} \mathrm{O}_{3} / \mathrm{Fe}_{3} \mathrm{O}_{4}$} & 1391 & 1350 & 41 & 86 & 183 & $\begin{array}{c}C \\
F e^{I I I}\end{array}$ & $\rightarrow$ & $\begin{array}{c}S \\
F e^{I I}\end{array}$ \\
\hline \multirow{8}{*}{$\mathrm{Co}-\mathrm{Cu}-\mathrm{O} \times(\mathrm{Cu})$} & 0.03 & 896 & 860 & 36 & 94.3 & 574 & \multirow{8}{*}{$\begin{array}{c}S \\
\mathrm{Co}^{I I I}\end{array}$} & \multirow{8}{*}{$\rightarrow$} & \multirow{8}{*}{$\begin{array}{c}M \\
C o^{I I}\end{array}$} \\
\hline & 0.1 & 867 & 845 & 22 & 97.4 & 570 & & & \\
\hline & 0.2 & 864 & 824 & 40 & 97.3 & 520 & & & \\
\hline & 0.25 & 863 & 820 & 43 & 99.7 & 503 & & & \\
\hline & 0.3 & 864 & 813 & 51 & 97.5 & 436 & & & \\
\hline & 0.4 & 864 & 816 & 48 & 93 & 327 & & & \\
\hline & 0.6 & 861 & 818 & 43 & 98.8 & 351 & & & \\
\hline & 0.8 & 867 & 813 & 54 & 93.4 & 212 & & & \\
\hline \multirow{4}{*}{$\mathrm{Co}-\mathrm{Fe}-\mathrm{O} \times(\mathrm{Fe})$} & 0.05 & 921 & 848 & 73 & 84.4 & 454 & \multirow{4}{*}{$\underset{C o^{I I I}}{S}$} & \multirow{4}{*}{$\rightarrow$} & \multirow{4}{*}{$\begin{array}{c}M \\
\mathrm{Co}^{I I}\end{array}$} \\
\hline & 0.1 & 931 & 896 & 35 & 83.9 & 365 & & & \\
\hline & 0.25 & 933 & 914 & 19 & 82.4 & 224 & & & \\
\hline & 0.4 & 941 & 945 & 4 & 82.5 & 51 & & & \\
\hline \multirow{6}{*}{$\mathrm{Mn}-\mathrm{Co}-\mathrm{O} \times(\mathrm{Co})$} & 0.5 & 989 (Ar) & - & - & 64.2 & 133 & \multirow{6}{*}{$\begin{array}{c}S \\
C o^{I I I}\end{array}$} & \multirow{6}{*}{$\rightarrow$} & \multirow{6}{*}{$\begin{array}{c}M \\
C o^{I I}\end{array}$} \\
\hline & 0.6 & $942(\mathrm{Ar})$ & - & - & 84.7 & 200 & & & \\
\hline & 0.7 & 930 & 877 & 53 & 96.7 & 306 & & & \\
\hline & 0.8 & 933 & 873 & 60 & 96.6 & 296 & & & \\
\hline & 0.9 & 920 & 871 & 49 & 97.9 & 427 & & & \\
\hline & 0.95 & 937 & 991 & 54 & 94.9 & 319 & & & \\
\hline
\end{tabular}


Table 1. Cont.

\begin{tabular}{|c|c|c|c|c|c|c|c|c|c|}
\hline \multirow{2}{*}{\multicolumn{2}{|c|}{ TCES System }} & \multicolumn{2}{|c|}{ Onset Temperature $\left({ }^{\circ} \mathrm{C}\right)$} & \multirow{3}{*}{$\begin{array}{c}\text { Temperature } \\
\text { Gap }\left({ }^{\circ} \mathrm{C}\right) \\
-\end{array}$} & \multirow{3}{*}{$\begin{array}{c}\begin{array}{c}\text { Conversion } \\
(\%)\end{array} \\
21.2\end{array}$} & \multirow{3}{*}{$\begin{array}{c}\begin{array}{c}\text { Exp. Reaction } \\
\text { Enthalpy (kJ/kg) }\end{array} \\
126\end{array}$} & \multirow{2}{*}{\multicolumn{3}{|c|}{$\begin{array}{l}\text { Phase Transition \& } \\
\text { Redox Couple }\end{array}$}} \\
\hline & & \multirow{2}{*}{$\begin{array}{c}\text { Reduction } \\
900\end{array}$} & \multirow{2}{*}{$\begin{array}{c}\text { Oxidation } \\
\text { no re-ox. }\end{array}$} & & & & & & \\
\hline \multirow{7}{*}{$\mathrm{Mn}-\mathrm{Cu}-\mathrm{O} \times(\mathrm{Cu})$} & 0.05 & & & & & & \multirow{3}{*}{$\begin{array}{c}\text { B } \\
M n^{I I I}\end{array}$} & \multirow{3}{*}{$\rightarrow$} & \multirow{3}{*}{$\begin{array}{c}\boldsymbol{H} \\
M n^{I I}\end{array}$} \\
\hline & 0.1 & 877 & no re-ox. & - & 10.7 & - & & & \\
\hline & 0.2 & 811 & no re-ox. & - & 1.6 & - & & & \\
\hline & 0.3 & 976 & 1040 & 64 & 90.8 & - & \multicolumn{3}{|c|}{-} \\
\hline & 0.4 & 960 & 969 & 9 & 96.9 & - & \multirow{3}{*}{$\begin{array}{c}S \\
C u^{I I}\end{array}$} & \multirow{3}{*}{$\rightarrow$} & \multirow{3}{*}{$\begin{array}{c}\mathbf{D} \\
\mathrm{Cu}\end{array}$} \\
\hline & 0.5 & 962 & 886 & 76 & 88.2 & - & & & \\
\hline & 0.8 & 954 & 1000 & 46 & 89.7 & 354 & & & \\
\hline \multirow{6}{*}{$M n-F e-O \times(F e)$} & 0.1 & 990 & 774 & 216 & 31 & 168 & $B$ & & $H$ \\
\hline & 0.15 & 981 & 870 & 111 & 99.1 & 171 & $M n^{I I I}$ & $\rightarrow$ & $M n^{I I}$ \\
\hline & 0.2 & 980 & 860 & 120 & 98.2 & 194 & \multirow{4}{*}{$\begin{array}{c}B \\
M n^{I I I}\end{array}$} & & \multirow{4}{*}{$\begin{array}{c}S \\
M n^{I I}\end{array}$} \\
\hline & 0.3 & 984 & 866 & 118 & 94.1 & 195 & & & \\
\hline & 0.4 & 998 & 903 & 95 & 95.3 & 189 & & & \\
\hline & 0.5 & 1014 & 937 & 77 & 94.7 & 189 & & & \\
\hline
\end{tabular}

\subsection{Co-Fe-O Mixed Oxide System}

The effects of the Fe incorporation to $\mathrm{Co}_{3} \mathrm{O}_{4}$ (initial phase: $\left.\left(\mathrm{Fe}_{\mathrm{x}} \mathrm{Co}_{1-\mathrm{x}}\right)_{3} \mathrm{O}_{4}\right)$ was studied for amounts of $\mathrm{Fe}$ up to $\mathrm{x}(\mathrm{Fe})=0.4$ (Figure 1), as there is no phase transition for this system below $1200^{\circ} \mathrm{C}$ in air for $\mathrm{x}(\mathrm{Fe})>0.6$ [35], which is the upper limit usually admitted for TCES application. Compared to pure $\mathrm{Co}_{3} \mathrm{O}_{4}$, the studied compositions feature lesser oxygen storage capacity (OSC) with increasing iron content (Figure 1a), which is partly ascribed to an increasing proportion of spinel phase which is not converted into monoxide for $0.1<\mathrm{x}(\mathrm{Fe})<0.6$, and to the presence of residual oxygen storage in the monoxide phase introduced by the iron addition.

A linear correlation between the variations in oxygen mass loss/gain and the reaction enthalpy is evidenced in Figure 2. It is in accordance with the experimental data obtained for the reaction enthalpy of Co-Fe-O mixed oxides.

A decrease in reaction enthalpy was also observed with the increasing addition of $\mathrm{Fe}$, from small amounts up to $\mathrm{x}(\mathrm{Fe})=0.4\left(51 \mathrm{~kJ} / \mathrm{kg}\right.$, against $597 \mathrm{~kJ} / \mathrm{kg}$ for pure $\left.\mathrm{Co}_{3} \mathrm{O}_{4}\right)$ (Figure 1b). Block et al. (2014) [27] previously described that the incorporation of iron to cobalt oxide may contribute to the $\mathrm{Co}_{3} \mathrm{O}_{4}$ stability when added in small amounts $(10 \%)$, by enhancing the microstructural stability of cobalt oxide while retaining suitable reaction enthalpies, whereas larger amounts of added iron oxide gradually reduce the reaction enthalpy of the redox systems. In contrast, a minor loss in oxygen exchange capacity upon cycling was evidenced for lower Fe contents $0.05<x(\mathrm{Fe})<0.1$ [35]. Concerning the Co-Fe-O system, the gravimetric energy storage density of the mixed oxides is lower than that of both pure cobalt oxide and iron oxide [27,35].

A noticeable decrease in the temperature gap between the reduction and oxidation reactions is also observed with the addition of $\mathrm{Fe}$ from $\mathrm{x}(\mathrm{Fe})=0.1$ to $\mathrm{x}(\mathrm{Fe})=0.4$ (Figure 1c), which is convenient to reduce the amount of energy required to switch between the charge and the discharge steps of the system. Overall, the transition temperature for both reduction and oxidation is increased with the addition of $\mathrm{Fe}$ to $\mathrm{Co}_{3} \mathrm{O}_{4}$. 
(a)

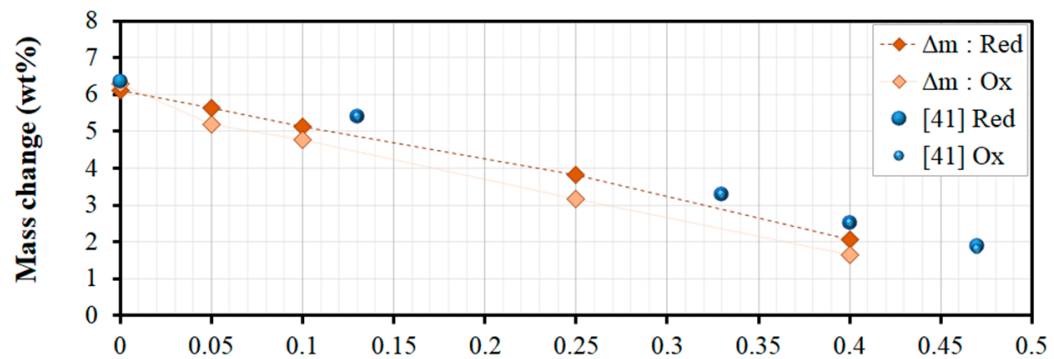

(b)

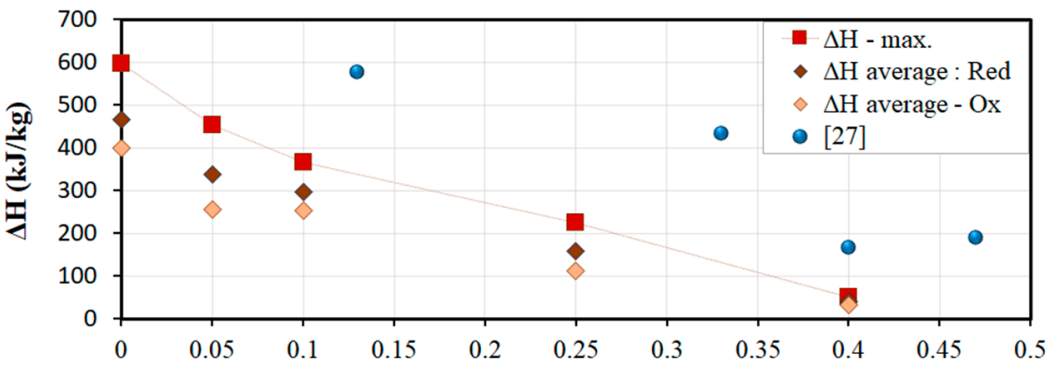

(c)

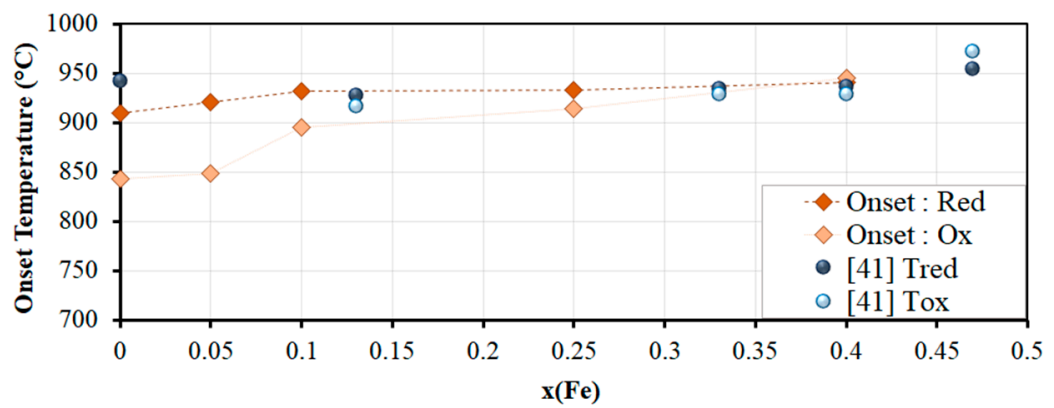

Figure 1. Mass variation (OSC), enthalpy change and onset temperatures of redox reactions measured for the Co-Fe-O system.

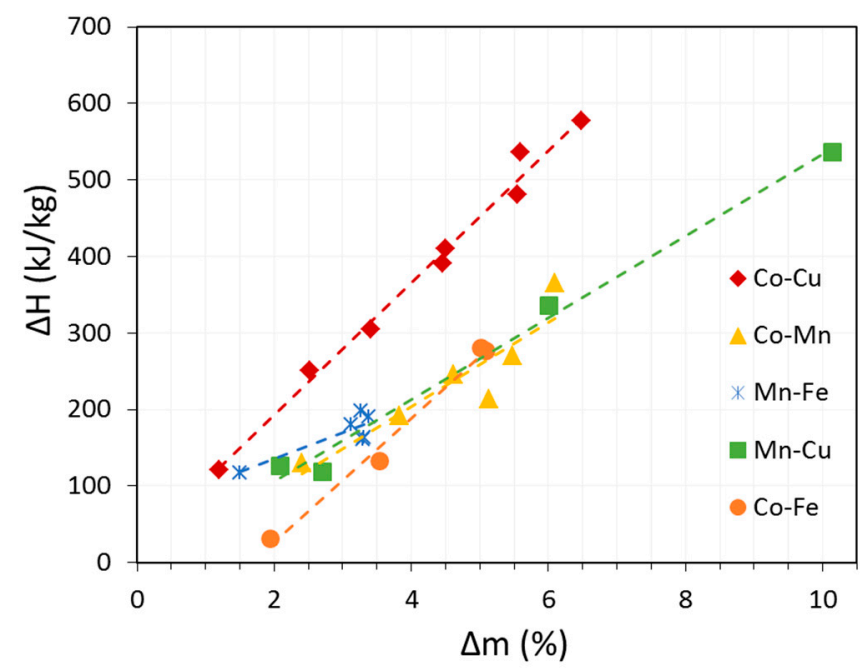

Figure 2. Correlation between measured enthalpy (average values from the reduction and oxidation reactions) and $\mathrm{OSC}(\Delta \mathrm{m})$ of $\mathrm{Co}-\mathrm{Fe}, \mathrm{Co}-\mathrm{Cu}, \mathrm{Mn}-\mathrm{Co}, \mathrm{Mn}-\mathrm{Fe}$ and $\mathrm{Mn}-\mathrm{Cu}$ mixed oxides.

\subsection{Co-Cu-O Mixed Oxide System}

The Co-Cu-O system shows very good reversibility and cycling stability for all the studied compositions up to $x(\mathrm{Cu})=0.8[36,41]$ (Figure 3a). With higher copper content in the mixed oxide, the transition temperature of the system becomes too close to the melting point, thus increasing the presence of sintering issues with increasing copper amounts. However, this phenomenon did not alter 
the reactivity of the materials. The OSC of this system also decreases, when compared to pure $\mathrm{Co}_{3} \mathrm{O}_{4}$, above $\mathrm{x}(\mathrm{Cu})=0.03$.

Similar to Co-Fe-O, a linear correlation was observed in the $\mathrm{Co}-\mathrm{Cu}-\mathrm{O}$ system between the OSC and the reaction enthalpy (Figure 2), since the decrease in OSC is accompanied by a linear decrease in the reaction enthalpy with increasing $\mathrm{Cu}$ amounts (Figure 3b). Depending on the composition, a lower enthalpy can be linked to a decrease in the reactive cobalt-containing phase, thus resulting in lower reaction enthalpies for compositions with higher copper amounts [41]. Motuzas et al. (2015) [46] studied the OSC of $\mathrm{Co}-\mathrm{Cu}$ mixed oxides and also observed a favored oxygen exchange with higher cobalt content $\left(\mathrm{Co}_{0.8} \mathrm{Cu}_{0.2} \mathrm{O}_{\mathrm{x}}\right)$, while the presence of copper oxide helped decreasing the temperature for the release of oxygen in cobalt oxide. The presence of non-reactive $\mathrm{CuO}$ for compositions around $x(\mathrm{Cu})=0.1$ was also reported to stabilize the microstructure of the material against sintering [41].

Nonetheless, the reaction enthalpy of the Co-Cu-O system remains above $200 \mathrm{~kJ} / \mathrm{kg}$ regardless of the $\mathrm{Cu}$ content, thus exhibiting high enough energy storage capacity to be of interest for TCES.

A noteworthy variation in reaction temperature occurs in the $\mathrm{Co}-\mathrm{Cu}-\mathrm{O}$ system since, on the one hand, the gap in temperature between reduction and oxidation decreases for $\mathrm{x}(\mathrm{Cu})<0.1$ (Figure 3c). On the other hand, the temperature difference is similar to that of the pure $\mathrm{Co}_{3} \mathrm{O}_{4}$ system for $0.1<\mathrm{x}(\mathrm{Cu})<0.8$ but both reduction and oxidation temperatures are shifted to lower values, thus providing an additional option to adapt the storage system to lower temperature conditions for energy storage application.

(a)

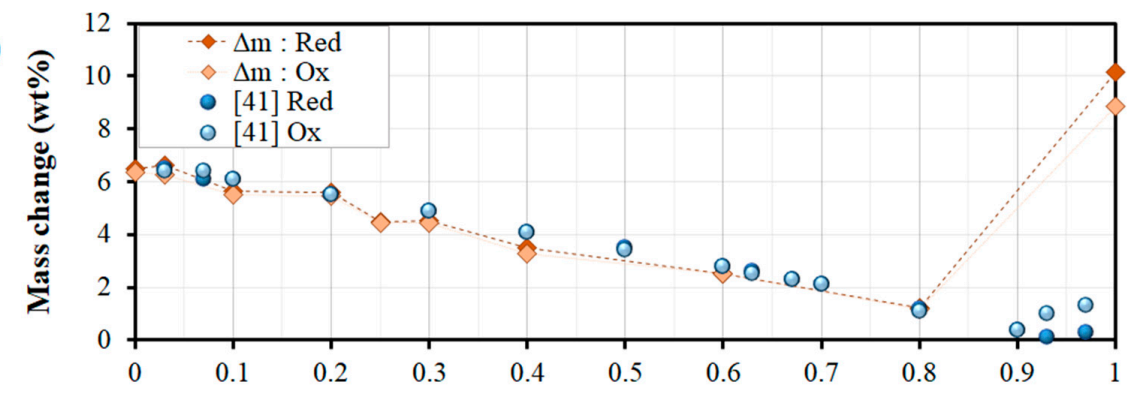

(b)

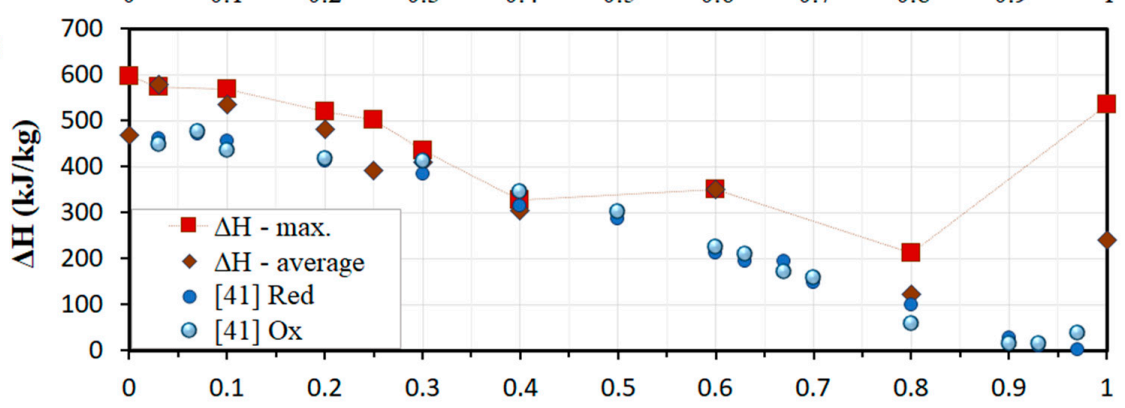

(c)

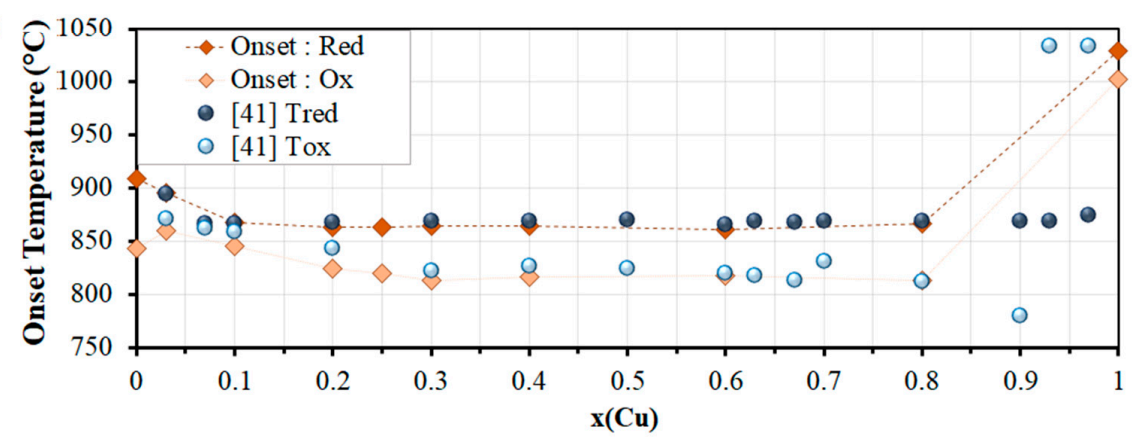

Figure 3. Mass variation (OSC), enthalpy change and onset temperatures of redox reactions measured for the $\mathrm{Co}-\mathrm{Cu}-\mathrm{O}$ system. 


\subsection{Mn-Fe-O Mixed Oxide System}

The cycling stability and reversibility of the redox reaction of $\mathrm{Mn}_{2} \mathrm{O}_{3} / \mathrm{Mn}_{3} \mathrm{O}_{4}$ was greatly improved by the incorporation of iron from $x(\mathrm{Fe})=0.15$ to $x(\mathrm{Fe})=0.5$ (Figure $4 \mathrm{a}$ ). This improvement concerning compositions above $x(\mathrm{Fe})=0.15$ was attributed to the transition into a cubic spinel phase with increased re-oxidation capability, whereas for smaller Fe content the presence of the tetragonal spinel phase (hausmannite) is responsible for the poor re-oxidation [35,47]. Very good cycling stability was also reported in other studies with the incorporation of $\mathrm{Fe}$ contents higher than $\mathrm{x}(\mathrm{Fe})=0.15$ in manganese oxide. The mixed oxide with the composition $\left(\mathrm{Mn}_{0.8} \mathrm{Fe}_{0.2}\right)_{2} \mathrm{O}_{3} /\left(\mathrm{Mn}_{0.8} \mathrm{Fe}_{0.2}\right)_{3} \mathrm{O}_{4}$ has shown good stability over 75 redox cycles due to the incorporation of Fe modifying the structure and enhancing the oxidation rate [44]. The mixed oxide composition $\left(\mathrm{Mn}_{0.75} \mathrm{Fe}_{0.25}\right)_{2} \mathrm{O}_{3}$ also showed cycling stability and reversibility over the course of a hundred redox cycles, although a change in the particles' morphology was noted [47].

Concerning the overall OSC of the material, there was no change and it remained similar to that of pure $\mathrm{Mn}_{2} \mathrm{O}_{3}$ and stable for all the studied compositions (Figure 4a).

The reaction enthalpy also remained somewhat similar for all the studied compositions $(0 \leq \mathrm{x}(\mathrm{Fe})$ $\leq 0.5$ ), with a slight increase noticeable for $x(F e)=0.2$ (Figure $4 b$ ). However, when compared with the reaction enthalpies measured by Carrillo et al. (2015), it is difficult to conclude on a clear variation in the reaction enthalpy for compositions between $0<x(\mathrm{Fe})<0.2$. Block et al. (2016) reported a measured enthalpy up to $232.7 \mathrm{~kJ} / \mathrm{kg}$ for $\mathrm{x}(\mathrm{Fe})=0.33$ [41].

The temperature hysteresis of the $\mathrm{Mn}_{2} \mathrm{O}_{3} / \mathrm{Mn}_{3} \mathrm{O}_{4}$ system is a concern which could be addressed with the $\mathrm{Fe}$ addition in an amount superior to $\mathrm{x}(\mathrm{Fe})=0.15$, from which a clear decrease in the temperature gap is evidenced between the reduction and the oxidation temperatures (Figure 4c).

(a)

(b)
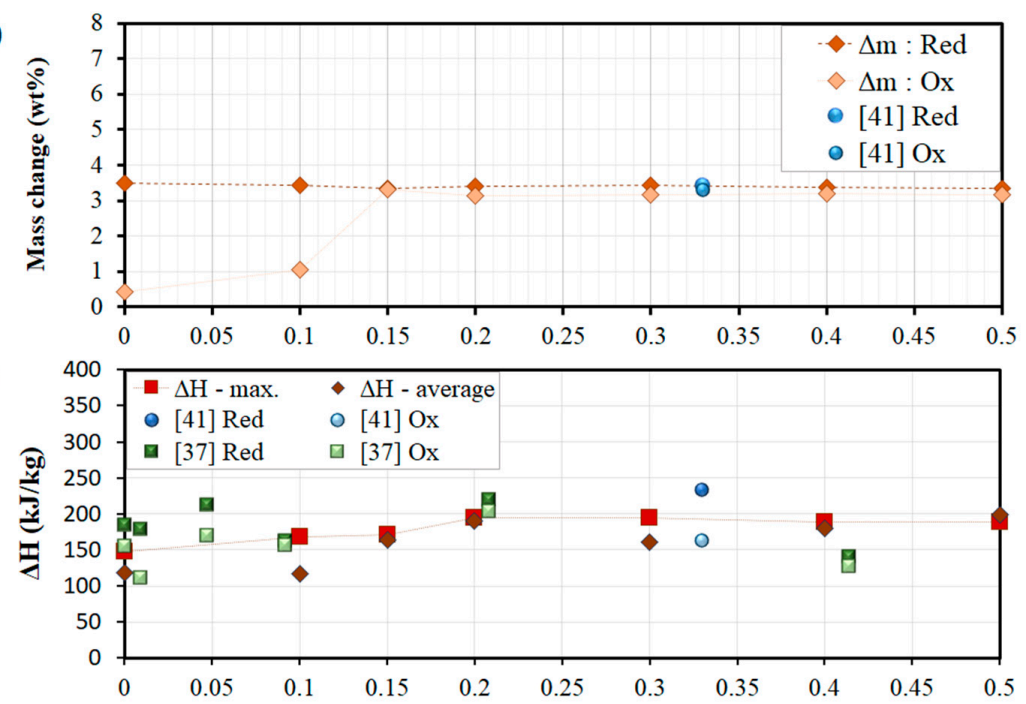

(c)

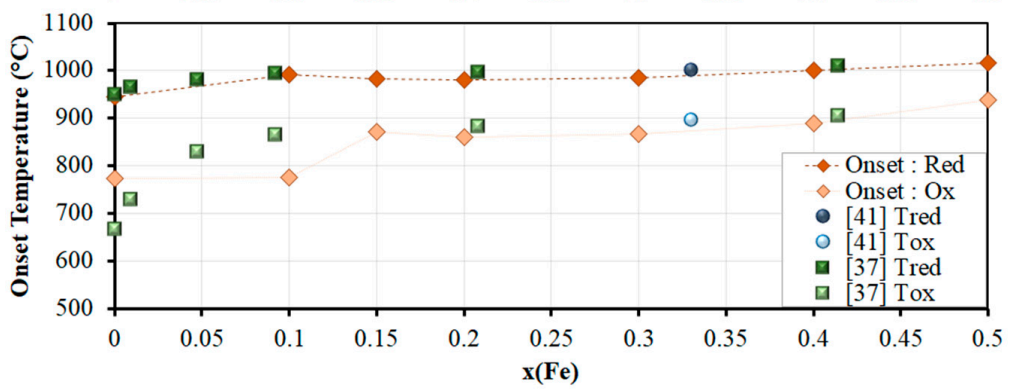

Figure 4. Mass variation (OSC), enthalpy change and onset temperatures of redox reactions measured for the $\mathrm{Mn}-\mathrm{Fe}-\mathrm{O}$ system. 


\subsection{Mn-Cu-O Mixed Oxide System}

Within the $\mathrm{Mn}-\mathrm{Cu}-\mathrm{O}$ system, the reaction reversibility is poor for the compositions ranging from $0 \leq x(\mathrm{Cu}) \leq 0.3$ (Figure $5 \mathrm{a}$ ), as the material transitions through the hausmannite phase during the reduction step, with low re-oxidation capability [36], as also previously observed for Mn-based systems $[35,36]$. The hausmannite phase can be avoided completely by choosing a composition within the range $0.4 \leq \mathrm{x}(\mathrm{Cu}) \leq 0.8$, for which a good cycling stability is then observed, along with an increased OSC when compared to pure $\mathrm{Mn}_{2} \mathrm{O}_{3}$. The oxygen exchange capacity of a Mn-Cu mixed oxide with $34 \mathrm{wt} \% \mathrm{CuO}$ was also investigated in a fluidized bed reactor and in TGA, and results showed complete cyclability for 18 cycles over the course of $35 \mathrm{~h}$ (reduction in $\mathrm{N}_{2}$ /oxidation in $10 \mathrm{vol} \%$ $\left.\mathrm{O}_{2}: \mathrm{N}_{2}\right)$ [48]. The addition of copper to $\mathrm{Mn}_{2} \mathrm{O}_{3}$ thus improves the cyclability of the material for $\mathrm{x}(\mathrm{Cu})$ $>0.3$, but the sintering issue remains at high temperature and increases with increasing amounts of added copper [36].

The energy storage capacity of the $\mathrm{Mn}-\mathrm{Cu}-\mathrm{O}$ mixed oxides was found equal $(148 \mathrm{~kJ} / \mathrm{kg}$ for $\mathrm{x}(\mathrm{Cu})=0.4$ and 0.5$)$ or higher $(354 \mathrm{~kJ} / \mathrm{kg}$ for $\mathrm{x}(\mathrm{Cu})=0.8)$ than that of pure $\mathrm{Mn}_{2} \mathrm{O}_{3}$ for compositions with $x(\mathrm{Cu})>0.4$ (Figure $5 \mathrm{~b}$ ). In order to avoid sintering and to keep the cost of the material at a minimum, mixed oxides of $\mathrm{Mn}-\mathrm{Cu}-\mathrm{O}$ with low copper amounts are preferred [36,41]. Block et al. (2016) [41] suggest that the composition at $x(\mathrm{Cu})=0.5$ is also an option because of its melting point shifting from $1070{ }^{\circ} \mathrm{C}$ for the redox reaction of pure copper oxide to $1180{ }^{\circ} \mathrm{C}$.

The reaction temperature is also modified by the addition of copper, as compositions with $x(C u) \leq 0.3$ show lower reduction temperature than $\mathrm{Mn}_{2} \mathrm{O}_{3}$ (Figure $5 \mathrm{c}$ ). The gap in temperature between oxidation and reduction is especially reduced for $x(C u)=0.4$ and $x(C u)=0.8$.

(a)

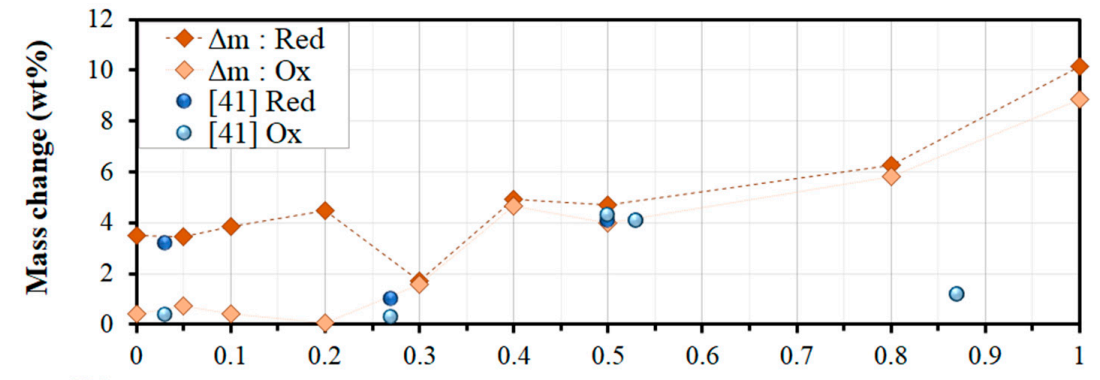

(b)

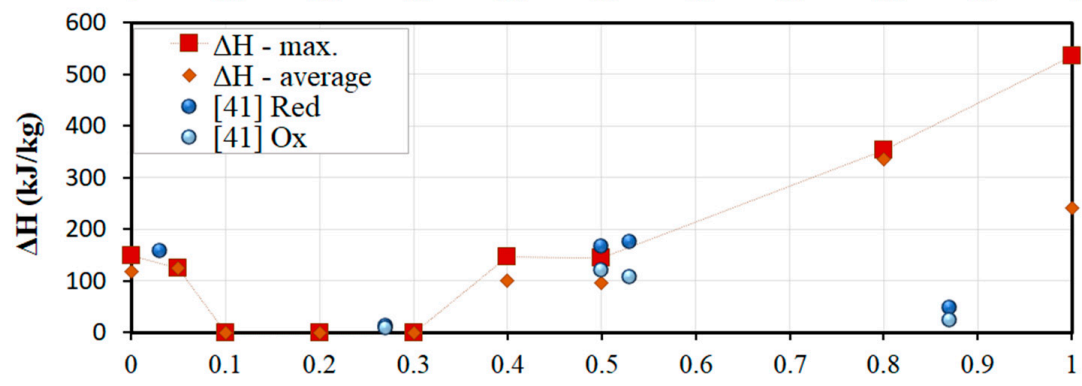

(c)

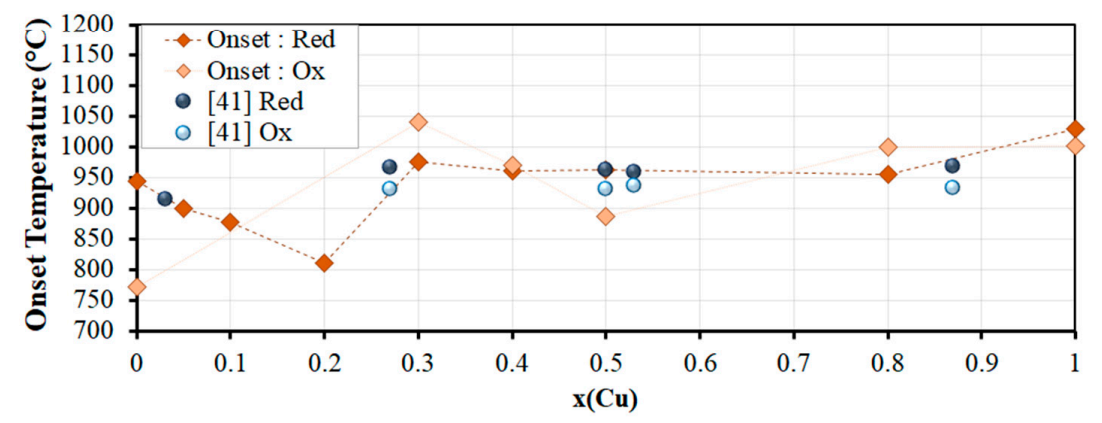

Figure 5. Mass variation (OSC), enthalpy change and onset temperatures of redox reactions measured for the $\mathrm{Mn}-\mathrm{Cu}-\mathrm{O}$ system. 


\subsection{Mn-Co-O Mixed Oxide System}

In the Mn-Co-O system, the mixed oxides with higher Co content exhibit better reversibility (Figure 6a) and higher reaction enthalpy, while the OSC is decreased with increasing amounts of $\mathrm{Mn}$ added (Figure 6b) [36,41]. For compositions with $x(\mathrm{Co})<0.4$, the low reaction reversibility and absence of re-oxidation is attributed again to the formation of the tetragonal spinel phase [36]. Nevertheless, the energy storage density remains higher for pure $\mathrm{Co}_{3} \mathrm{O}_{4}$ when compared to the mixed oxides within this system (Figure $6 \mathrm{~b}$ ), and the OSC and the reaction enthalpy follow a similar evolution (Figures 2 and $6 a, b)$. However, the transition temperatures of the Mn-Co mixed oxides are higher than the transition temperatures of the pure cobalt oxide and manganese oxide (Figure 6c).

(a)

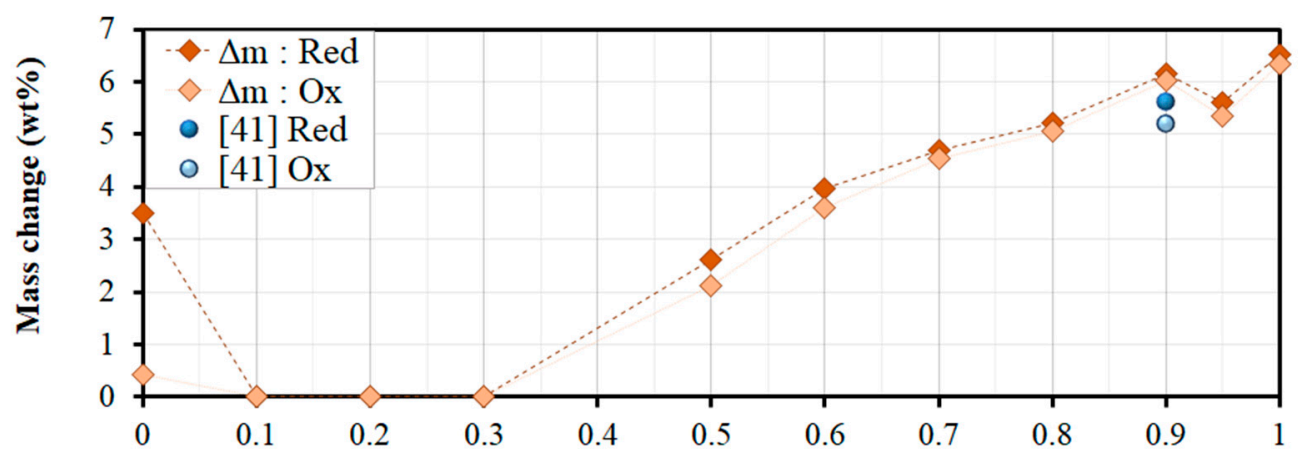

(b)

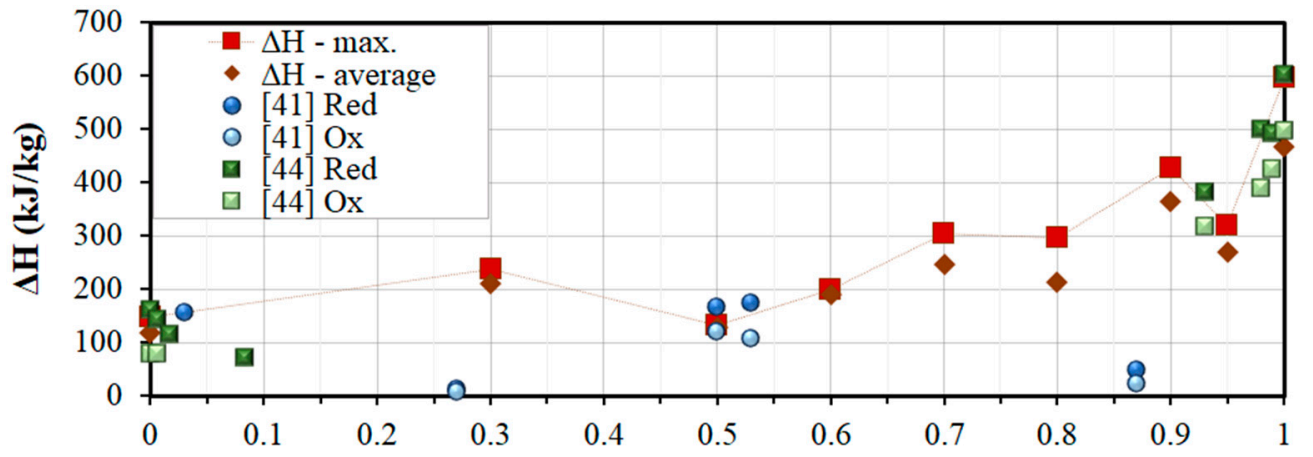

(c)

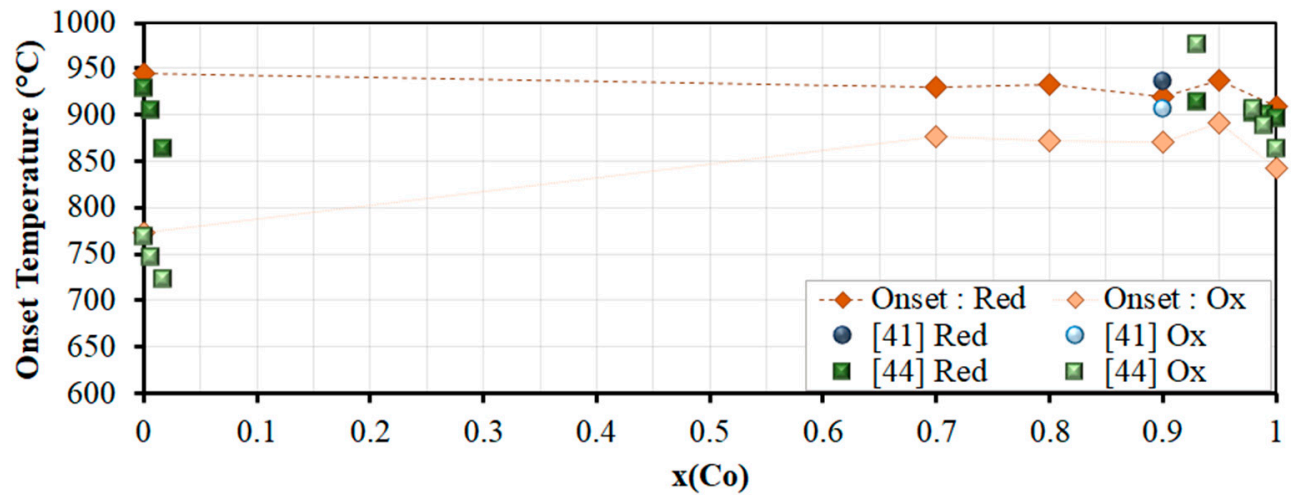

Figure 6. Mass variation (OSC), enthalpy change and onset temperatures of redox reactions measured for the Mn-Co-O system.

\section{Contribution of Thermodynamic Calculations}

Due to the implementation of high temperature chemical reactions in TCES processes, considerations related to thermodynamic equilibria are of high interest for the design of the most performant materials. Indeed, a precise thermodynamic description of the system $\mathrm{MM}^{\prime} \mathrm{O}_{(\mathrm{ox})}-\mathrm{MM}^{\prime} \mathrm{O}_{(\mathrm{red})}-\mathrm{O}_{2}(\mathrm{~g})$ makes it possible to determine the maximum achievable conversion yield, to target the most suitable compositions and operating conditions, and to understand experimental results obtained at lab scale. 
However, as illustrated by the case of the mixed oxides considered in this work, a full thermodynamic description of the systems is not always available. There are three major levels of thermodynamic description for such systems:

- Existence of an accurate phase diagram for the pseudo-binary system,

- Existence of thermochemical data such as enthalpy of mixing between phases or heat capacity functions $\left(\mathrm{c}_{\mathrm{p}(\mathrm{T})}\right)$ for all phases of the system,

- Existence of a model established with the Calphad method, allowing equilibrium computations with a dedicated software.

When a full model is available, various equilibrium computations can be performed, such as the plot of phase diagrams or the calculation of the system equilibrium at various compositions and temperatures. This provides, for each composition and at each temperature step, the phase assemblage, the cationic distribution in each solution phases, the theoretical mass change (i.e., oxygen storage capacity), as well as the enthalpy variations of the system. As summarized in Table 2, three of the five systems considered here ( $\mathrm{Co}-\mathrm{Fe}-\mathrm{O}, \mathrm{Co}-\mathrm{Cu}-\mathrm{O}$ and $\mathrm{Mn}-\mathrm{Fe}-\mathrm{O})$ benefit from a complete thermodynamic description including one or several models. However, this is not the case for the Mn-Co-O system, for which the phase diagram at temperatures below $800^{\circ} \mathrm{C}$ is not firmly established [49], nor for the $\mathrm{Mn}-\mathrm{Cu}-\mathrm{O}$ system, for which phase diagrams with large discrepancies have been published [50,51]. Among the global $\mathrm{Mn}-\mathrm{Co}-\mathrm{Fe}-\mathrm{Cu}-\mathrm{O}$ system, the last ternary sub-system, $\mathrm{Cu}-\mathrm{Fe}-\mathrm{O}$, benefits from a large amount of experimental data and a robust model [52].

Table 2. Summary of available phase diagrams and thermodynamic models for the ternary systems $\mathrm{Cu}-\mathrm{Fe}-\mathrm{O}, \mathrm{Co}-\mathrm{Fe}-\mathrm{O}, \mathrm{Co}-\mathrm{Cu}-\mathrm{O}, \mathrm{Mn}-\mathrm{Fe}-\mathrm{O}, \mathrm{Mn}-\mathrm{Cu}-\mathrm{O}$ and $\mathrm{Mn}-\mathrm{Co}-\mathrm{O}$ in air [47-58].

\begin{tabular}{ccc}
\hline Oxide System & Phase Diagram & Model \\
\hline Cu-Fe-O & Jacob, 1977 [53] & Shishin, 2013 [52] \\
\hline Co-Fe-O & Zhang, 2013 [54] & $\begin{array}{c}\text { Jung, 2004 [55] } \\
\text { Zhang, 2013 [54] }\end{array}$ \\
\hline Co-Cu-O & Zabdyr, 2002 [56] & Zabdyr, 2002 [56] \\
\hline Mn-Fe-O & Crum, 2009 [57] & $\begin{array}{c}\text { Kjellqvist, 2010 [58] } \\
\text { Kang, 2016 [47] }\end{array}$ \\
\hline Mn-Co-O & Golikov, 1985 [49] & None \\
\hline Mn-Cu-O & $\begin{array}{c}\text { Driessens, 1967 [50] } \\
\text { Wei, 2009 [51] }\end{array}$ & None \\
\hline
\end{tabular}

Depending on the level of description of the mixed oxide systems, several applications of thermodynamics are described in the following sections. The calculations were carried out with the FactSage software [59].

\subsection{Hausmannite Phase Boundaries}

One of the major conclusions of the experimental data compiled in Section 3, is that, for Mn-containing systems, the hausmannite phase formation has to be avoided, because of the poor reversibility of the phase transition during the cooling step of the thermal cycle. As illustrated with the three binary phase diagrams plotted in Figure 7, the binary systems based on Mn must contain a substantial amount (about 0.2 in molar fraction) of copper or iron oxide to make sure that the thermal cycle will not favor the appearance of the hausmannite phase at any temperature. In the case of cobalt additions, the hausmannite phase is stable on a much larger composition range. 

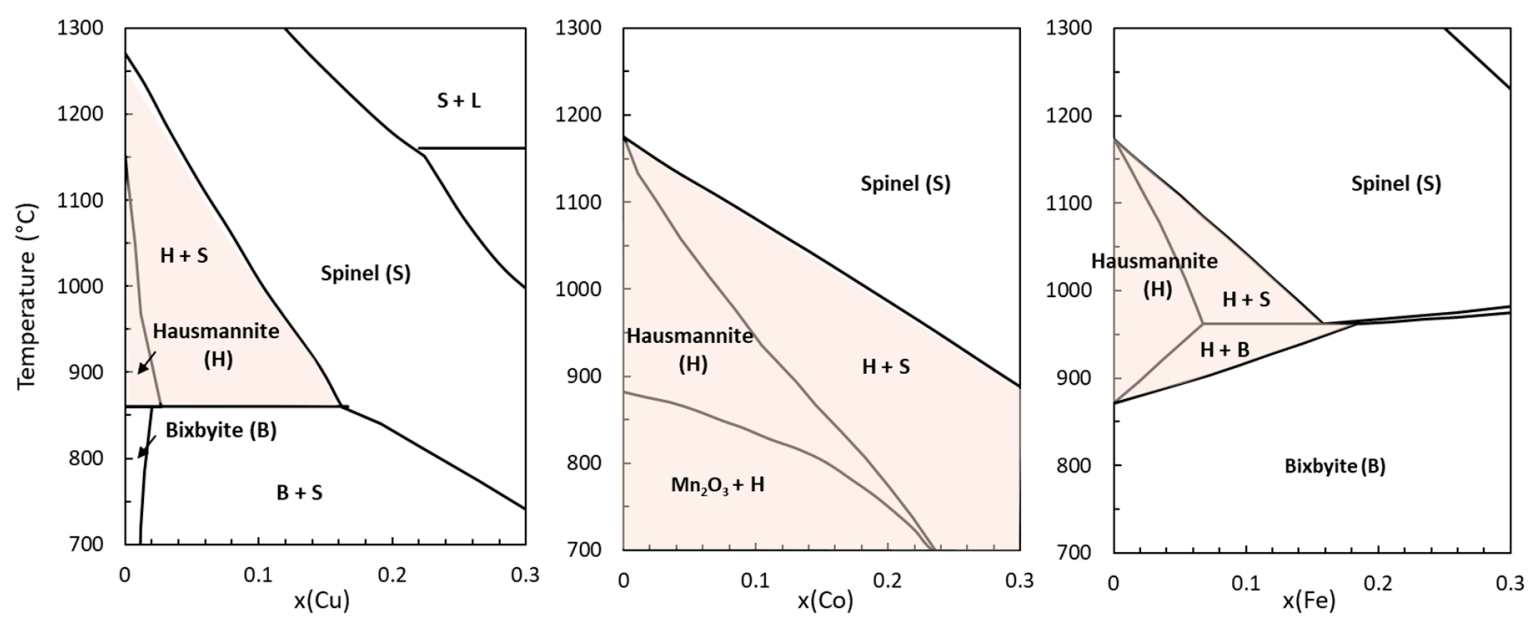

Figure 7. Mn-rich part of the Mn-Cu, Mn-Co and Mn-Fe phase diagrams in air (replotted from [49,51,57]).

The mixing of three metal oxides, rarely envisaged in TCES studies [60], can also be evaluated thanks to ternary phase diagrams. The only diagram of this type described in the literature is $\mathrm{Mn}-\mathrm{Co}-\mathrm{Fe}-\mathrm{O}$ in air [61], for which the phase boundaries of Hausmannite at 800 and $1000{ }^{\circ} \mathrm{C}$ have been reproduced in Figure 8. This diagram shows that the combination of iron and cobalt additions does not significantly reduce the stability range of the hausmannite phase.

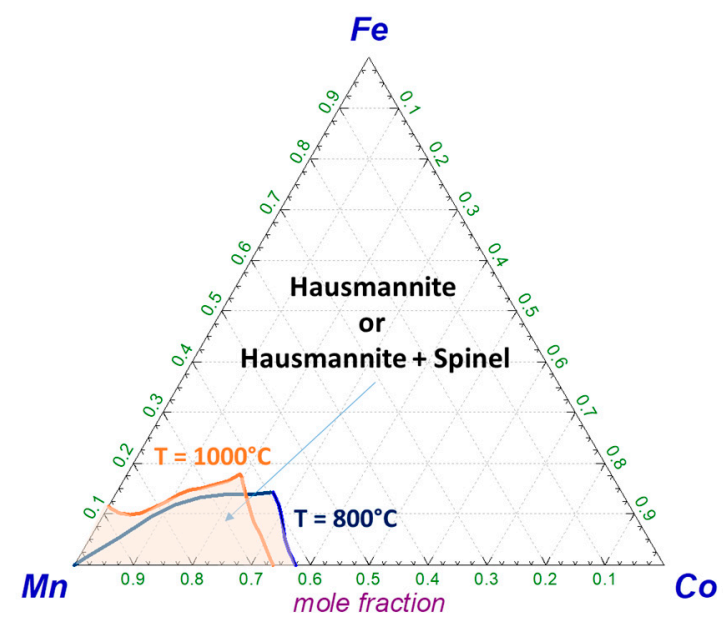

Figure 8. Composition domain containing the Hausmannite phase in the ternary system Mn-Co-Fe-O in air, at 800 and $1000^{\circ} \mathrm{C}$ (from [61]).

Apart from the diagrammatic data discussed here, the use of a thermodynamic model is a strong support to explore a larger set of operation conditions. For instance, in the system Mn-Fe-O, equilibrium calculations show that the decrease of oxygen partial pressure in the gas phase is beneficial to the stability of the hausmannite phase (Figure 9). At low oxygen partial pressure, more Fe thus is required to stabilize the spinel phase. 


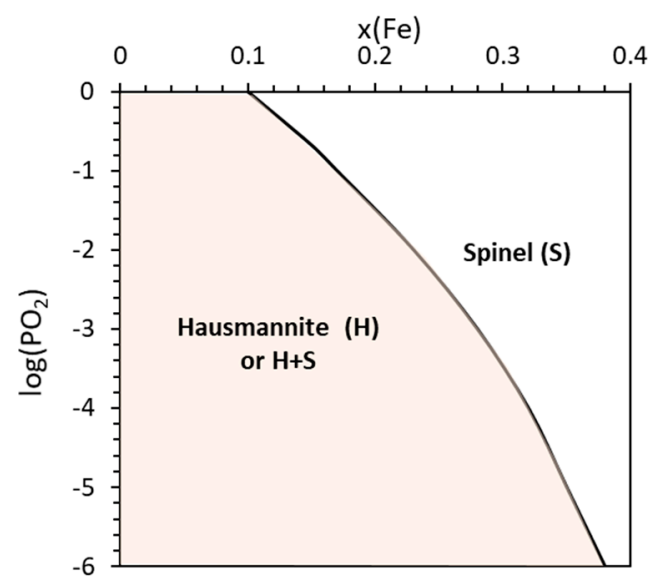

Figure 9. Calculated minimal amount of Fe in the Mn-Fe-O system in order to avoid the formation of the hausmannite phase at any temperature (model from [47]).

\subsection{Phase Transitions in Mixed Oxide Systems}

When dealing with solid-gas reactions involved in TCES processes, one must keep in mind a fundamental difference between single metal oxides and oxide mixtures. Indeed, according to the Gibbs' phase rule, the redox reactions (Equations (2) and (3)) for a single metal oxide occur at constant temperature. Conversely, with two metal oxides in the system, the variance increases, and the coexistence of two solid phases can occur on a large temperature and composition range.

A few typical examples of such behaviors are provided in Figure 10. The first case (Figure 10a,b) concerns the behavior of a single metal oxide, here $\mathrm{Co}_{3} \mathrm{O}_{4}$, with a phase transition occurring at $890{ }^{\circ} \mathrm{C}$. Conversely, the phase transition between the spinel $\left(\mathrm{Co}_{0.75} \mathrm{Fe}_{0.25}\right) \mathrm{O}_{4}$ and the monoxide $\mathrm{Co}_{0.75} \mathrm{Fe}_{0.25} \mathrm{O}$ (Figure 10c,d) occurs on a very large temperature range, between 935 and $1460{ }^{\circ} \mathrm{C}$. However, most of the conversion of the spinel takes place in the first $100^{\circ} \mathrm{C}$, and the enthalpy variation is also concentrated in this temperature range. This means that the maximal operating temperature does not need to be very high in order to store most of the achievable heat. Conversely, in the case of the conversion of the bixbyite $\left(\mathrm{Mn}_{0.10} \mathrm{Fe}_{0.90}\right)_{2} \mathrm{O}_{3}$ into the spinel $\left(\mathrm{Mn}_{0.10} \mathrm{Fe}_{0.90}\right)_{3} \mathrm{O}_{4}$ (Figure 10e,f), the concomitant formation of the hausmannite phase spreads the phase transition on about $200{ }^{\circ} \mathrm{C}$, which implies a larger temperature of operation for the thermochemical cycle.
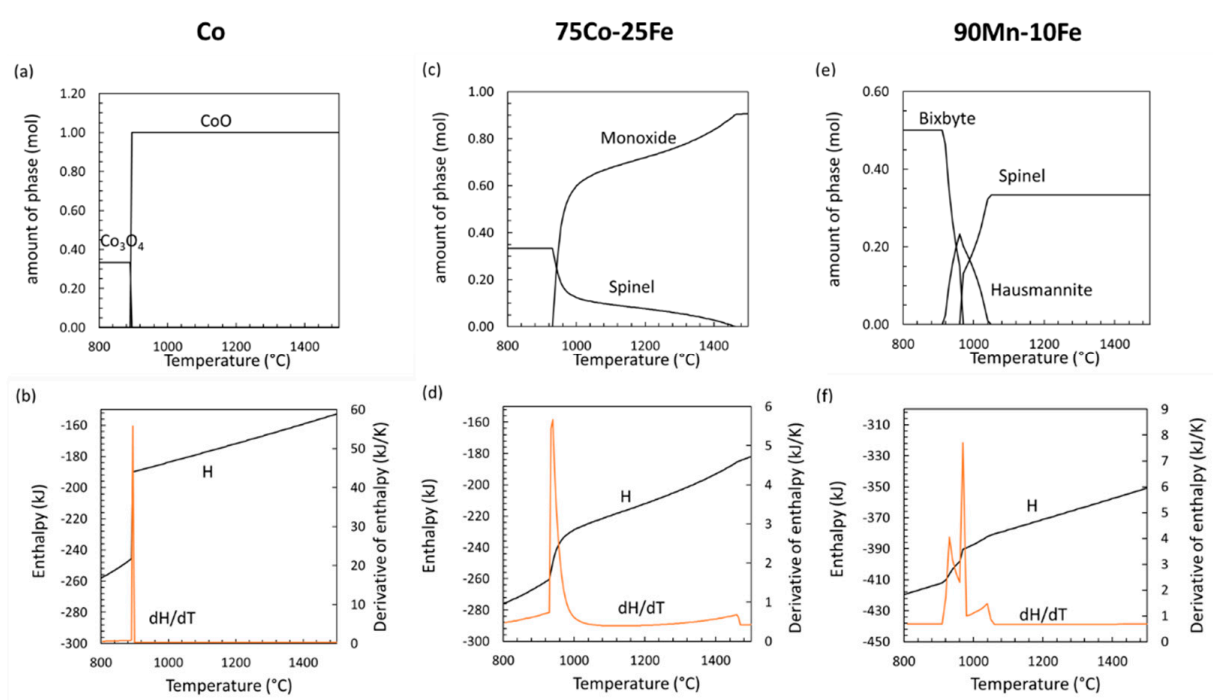

Figure 10. Calculation of the influence of temperature on $(\mathbf{a}, \mathbf{c}, \mathbf{e})$ the phase assemblage evolution and $(\mathbf{b}, \mathbf{d}, \mathbf{f})$ the system enthalpy, for three oxide systems in air. 


\subsection{Calculations in the $\mathrm{Cu}-\mathrm{Fe}$-O System}

In the present work, no experimental measurements were carried out in the $\mathrm{Cu}-\mathrm{Fe}-\mathrm{O}$ system. However, the existence of a full thermodynamic model [52] makes it possible to evaluate the potentialities of such mixed oxides for the purpose of TCES applications.

As mentioned in Section 3, one of the main constraints regarding Cu-containing redox systems is to avoid the formation of a liquid phase. As shown by the phase diagram plotted in Figure 11a, some liquid phase forms at $1048{ }^{\circ} \mathrm{C}$ for $0<\mathrm{x}(\mathrm{Fe})<0.50$, due to the presence of an eutectic at $\mathrm{x}(\mathrm{Fe})=0.15$. Meanwhile, the minimal temperature to reach in order to reduce $\mathrm{Cu}^{\mathrm{II}}$ into $\mathrm{Cu}^{\mathrm{I}}$ is $1028^{\circ} \mathrm{C}$. Thus, in the composition range $0<x(\mathrm{Fe})<0.50$, the addition of iron to copper oxide does not solve the problem of a very narrow window of operating temperature.

Figure $11 \mathrm{~b}$ presents the mass variation (i.e., the OSC) in the whole $\mathrm{Cu}-\mathrm{Fe}$ composition range, for various maximal cycle temperatures. In agreement with the two compositions studied by Block et al. (2016) [41], the calculations show that the addition of iron to copper oxide decreases the OSC if the maximal temperature is fixed at $1040^{\circ} \mathrm{C}$. For high iron content $(x(\mathrm{Fe})>0.66)$, the mass variation is very low. Indeed, in this case the TCES properties rely on the $\mathrm{Fe}^{\mathrm{III}} / \mathrm{Fe}^{\mathrm{II}}$ redox reaction, which requires much higher temperatures (above $1200^{\circ} \mathrm{C}$ ). Figure $11 \mathrm{~b}$ also clearly illustrates that a maximal temperature lower than $1040^{\circ} \mathrm{C}$ implies a low OSC for most of the $\mathrm{Cu}$-Fe compositions.

Notably, the calculations evidence that the case of pure delafossite compound $\mathrm{CuFeO}_{2}(\mathrm{x}(\mathrm{Fe})=0.5)$ may constitute the best compromise in the $\mathrm{Cu}-\mathrm{Fe}-\mathrm{O}$ systems. This stoichiometric compound allows for a higher maximal temperature of operation before decomposition $\left(1075^{\circ} \mathrm{C}\right.$ instead of $\left.1048^{\circ} \mathrm{C}\right)$, with an OSC value of $4.9 \%$ as already confirmed by experimental studies devoted to delafossite properties [62], and a calculated transition enthalpy of $206 \mathrm{~kJ} / \mathrm{kg}$. This observation calls for a deeper investigation of the potentialities of $\mathrm{CuFeO}_{2}$ for TCES applications.
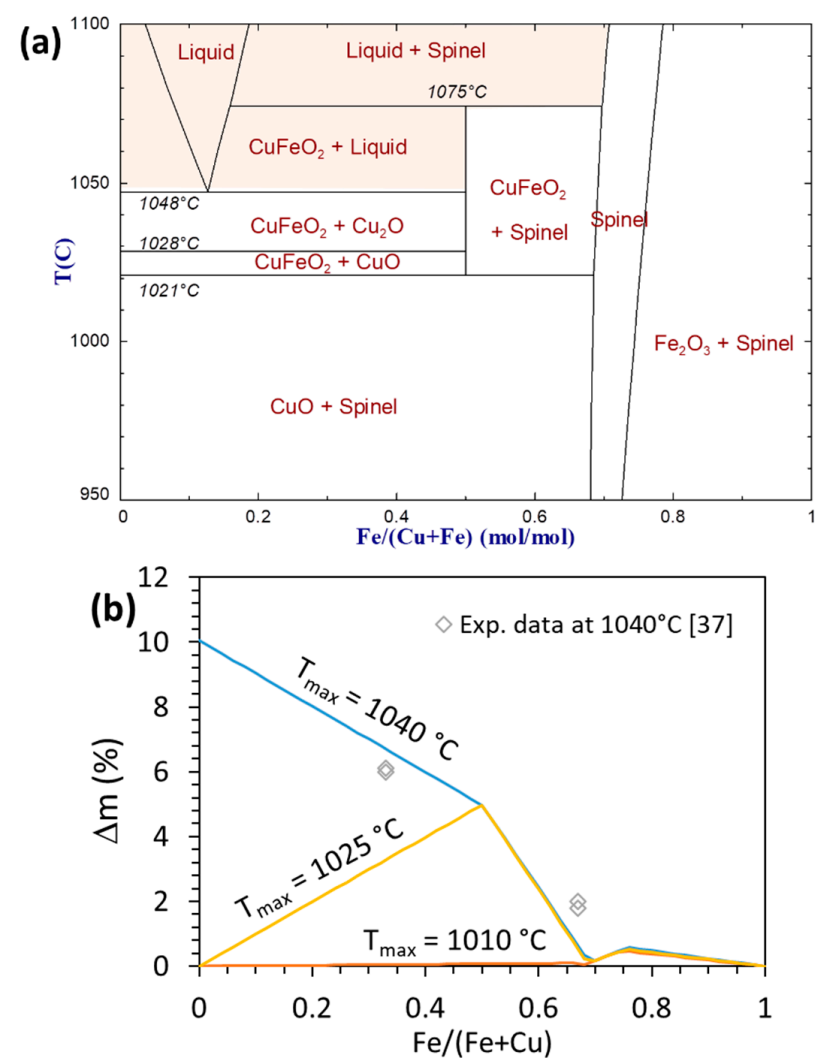

Figure 11. (a) Calculated phase diagram (model from [52]) of the $\mathrm{Cu}-\mathrm{Fe}-\mathrm{O}$ system in air, with highlight on the presence of the liquid phase (b) Evolution of mass change with composition for cycles between $\mathrm{T}_{\min }=800{ }^{\circ} \mathrm{C}$ and $\mathrm{T}_{\max }=1010,1025$ and $1040{ }^{\circ} \mathrm{C}$. 


\section{Discussion and Conclusions}

Thermochemical energy storage (TCES) is a promising route for the long-term storage of solar energy in the form of chemical bonds involving metal oxide systems. Indeed, the use of metal oxides for this application brings interesting alternative to other solid-gas systems because air can advantageously be used in open loop as both the reacting gas $\left(\mathrm{O}_{2}\right)$ in the reversible reactions and the heat transfer fluid (energy carrier from or to the storage medium). To cope with the noticeable challenges for developing reliable energy storage materials applied to solar power plants, binary and ternary metal oxide systems are considered. Their utilization could indeed alleviate the main critical issues related to singles oxides (cost and toxicity issues for Co oxide, poor reversibility due to slow oxidation rate for Mn oxide), and improved materials characteristics could be achieved such as resistance to sintering, compatible transition temperature, complete reaction reversibility, and suitable energy storage capacity.

Cobalt-based and manganese-based oxides have been investigated and compared with recent literature data in order to summarize the suitability of mixed oxides systems for TCES application at high temperature. The properties of mixed oxides regarding their energy storage capacity, redox reaction reversibility/cyclability, reaction temperature and hysteresis gap, were evaluated for the following systems: $\mathrm{Co}-\mathrm{Fe}-\mathrm{O}, \mathrm{Co}-\mathrm{Cu}-\mathrm{O}, \mathrm{Mn}-\mathrm{Fe}-\mathrm{O}, \mathrm{Mn}-\mathrm{Cu}-\mathrm{O}$ and $\mathrm{Mn}-\mathrm{Co}-\mathrm{O}$. Concerning cobalt-based systems, the addition of iron greatly decreases the OSC of the material, and the respective pure oxides show a higher reaction enthalpy than the mixed oxides of the Co-Fe-O system. However, the reaction temperature is positively impacted, as the hysteresis gap is reduced for compositions with $0.1 \leq \mathrm{x}(\mathrm{Fe})$ $\leq 0.4$. In addition, small amounts of added $\mathrm{Fe}, \mathrm{x}(\mathrm{Fe}) \leq 0.1$, may contribute to the thermal stability of $\mathrm{Co}_{3} \mathrm{O}_{4}$. From these observations, the incorporation of $\mathrm{Fe}$ around $\mathrm{x}(\mathrm{Fe})=0.1$ might be relevant to obtain a TCES material with enhanced stability, lower temperature gap between reaction steps, still high enough energy storage density (even though lower than that of the pure Co oxide), slightly lower cost, and possible use for higher temperature application, when compared to pure $\mathrm{Co}_{3} \mathrm{O}_{4}$.

The mixed oxides investigated in the Co-Cu-O system retain high reaction enthalpy (over $200 \mathrm{~kJ} / \mathrm{kg}$ ) and show good stability over several redox cycles. Similar to the Co-Fe-O system, the reaction enthalpy reported for the $\mathrm{Co}-\mathrm{Cu}$ mixed oxides decreases with increasing amounts of added $\mathrm{Cu}$. The OSC of the mixed oxides follows the same trend, except for a very small $\mathrm{Cu}$ amount, $\mathrm{x}(\mathrm{Cu})=0.03$, for which the OSC is unchanged when compared to pure $\mathrm{Co}_{3} \mathrm{O}_{4}$. Furthermore, previous literature data attracted attention to low $\mathrm{Cu}$-content compositions, especially around $\mathrm{x}(\mathrm{Cu})=0.1$, which was reported to hinder the material sintering, thus enhancing the stability of $\mathrm{Co}_{3} \mathrm{O}_{4}$ over repeated redox cycles, and improving its reaction kinetics. In addition, the addition of $\mathrm{Cu}$ to cobalt oxide reduces the transition temperature, thus providing a tunable option for storage systems requiring a different operating temperature.

The incorporation of $\mathrm{Co}$ into $\mathrm{Mn}_{2} \mathrm{O}_{3}$ contributed to the enhancement of the material properties, but both the OSC and energy storage capacity decrease with increasing amounts of $\mathrm{Mn}$. The Mn-Co-O mixed oxides with a majority of cobalt in the composition might be an alternative, as these materials show good reaction reversibility and suitable reaction enthalpies. They could further reduce the cost of the storage system, as compared to pure $\mathrm{Co}_{3} \mathrm{O}_{4}$, taking into account that their performances are however by far lower than those of pure $\mathrm{Co}_{3} \mathrm{O}_{4}$.

Concerning the Mn-based system with $\mathrm{Cu}$ addition, compositions ranging from $\mathrm{x}(\mathrm{Cu})=0.4$ to $\mathrm{x}(\mathrm{Cu})=0.8$ show a good reversibility, higher OSC and similar reaction enthalpy than pure $\mathrm{Mn}_{2} \mathrm{O}_{3}$. The gap in temperature between the charge and discharge steps is especially reduced for $\mathrm{x}(\mathrm{Cu})=0.4$. When compared with literature data, the compositions with $\mathrm{x}(\mathrm{Cu})=0.5$ and $\mathrm{x}(\mathrm{Cu})=0.8$ also demonstrate suitable properties. Because higher $\mathrm{Cu}$ amounts imply increased effect of sintering and higher cost, the composition at $\mathrm{x}(\mathrm{Cu})=0.8$ should be thus avoided. From $\mathrm{x}(\mathrm{Cu})=0.3$, a good reaction reversibility is observed but a low OSC, whereas compositions with lower $\mathrm{Cu}$ content show low reaction reversibility due to the presence of the hausmannite phase. Similarly, the Fe addition shows a positive impact on $\mathrm{Mn}_{2} \mathrm{O}_{3}$ cycling activity. Reversibility and stability over redox cycles are achieved with $\mathrm{Fe}$ addition above $\mathrm{x}(\mathrm{Fe})=0.15$, while the OSC remains stable. The enthalpy also remains unchanged (around $190 \mathrm{~kJ} / \mathrm{kg}$ for $\times(\mathrm{Fe})$ between 0.15 and 0.50). Besides, the temperature gap between 
the reduction and oxidation is decreased with the addition of iron above $x(\mathrm{Fe})=0.15$. The low material re-oxidation at low Fe content $(x(\mathrm{Fe})<0.15)$ comes from the formation of the tetragonal spinel phase (hausmannite). The hausmannite phase is no more stable when increasing the Fe content, and heating leads to a transition into a cubic spinel phase with enhanced re-oxidation capabilities.

In conclusion, the addition of iron to $\mathrm{Co}_{3} \mathrm{O}_{4}$ and $\mathrm{Mn}_{2} \mathrm{O}_{3}$ demonstrates the possible tuning of the systems temperatures to higher temperatures, while also reducing the hysteresis gap for both materials depending on the composition. The addition of $\mathrm{Cu}$ to $\mathrm{Co}_{3} \mathrm{O}_{4}$ also shifts the transition temperature to lower temperature. The $\mathrm{Mn}_{2} \mathrm{O}_{3}$ performance is greatly improved with the addition of a secondary metal in sufficient amounts to avoid the hausmannite phase formation during the heating. Although some compositions within $\mathrm{Mn}-\mathrm{Cu}$ and $\mathrm{Mn}-\mathrm{Co}$ systems are performant, $\mathrm{Mn}-\mathrm{Fe}$ mixed oxides can exhibit high performance and be cost-effective due to the high availability of iron. Significant performance improvements can thus be achieved when considering mixed metal oxides and the limitations associated to both Co and Mn oxides (low re-oxidation yield, poor reversibility, large temperature gap between redox reactions, scarce availability and high cost) can be alleviated with secondary metal additives. The oxygen storage capacity and energy storage density stand out from a linear correlation that was unraveled for each type of binary oxide system, paving the way for the possible optimization of the heat storage capacity via the improvement of the oxygen exchange rates.

In addition, thermodynamic modelling and equilibrium calculations were shown to be a relevant support for predicting reliably the behavior of mixed oxide systems and phase transitions. The results provided consistent transition temperatures, oxygen storage capacities and enthalpies. The application of suitable models provided new physical insights into the role of secondary metal addition on the redox properties' improvement of Co and Mn-based oxides. The calculations also highlighted that the $\mathrm{CuFeO}_{2}$ stoichiometric compound might be a relevant candidate material. The identification of new suitable mixed oxides could become possible with the development of new thermodynamic models encompassing large multi-component systems, which then would allow the selection of different transition metals for tuning the redox properties of mixed metal oxides for TCES applications.

Author Contributions: Data curation, S.A. and L.C.; Investigation, L.A., S.A. and L.C.; Supervision, S.A.; Writing-original draft, L.A.; Writing-review and editing, S.A. and L.C.

Funding: This research received no external funding.

Conflicts of Interest: The authors declare no conflict of interest.

\section{References}

1. Pardo, P.; Deydier, A.; Anxionnaz-Minvielle, Z.; Rougé, S.; Cabassud, M.; Cognet, P. A review on high temperature thermochemical heat energy storage. Renew. Sustain. Energy Rev. 2014, 32, 591-610. [CrossRef]

2. Yan, T.; Wang, R.Z.; Li, T.X.; Wang, L.W.; Fred, I.T. A review of promising candidate reactions for chemical heat storage. Renew. Sustain. Energy Rev. 2015, 43, 13-31. [CrossRef]

3. Abedin, A.H. A Critical Review of Thermochemical Energy Storage Systems. Open Renew. Energy J. 2011, 4, 42-46. [CrossRef]

4. Pelay, U.; Luo, L.; Fan, Y.; Stitou, D.; Rood, M. Thermal energy storage systems for concentrated solar power plants. Renew. Sustain. Energy Rev. 2017, 79, 82-100. [CrossRef]

5. Ströhle, S.; Haselbacher, A.; Jovanovic, Z.R.; Steinfeld, A. The effect of the gas-solid contacting pattern in a high-temperature thermochemical energy storage on the performance of a concentrated solar power plant. Energy Environ. Sci. 2016, 9, 1375-1389. [CrossRef]

6. Bayon, A.; Bader, R.; Jafarian, M.; Fedunik-Hofman, L.; Sun, Y.; Hinkley, J.; Miller, S.; Lipiński, W. Techno-economic assessment of solid-gas thermochemical energy storage systems for solar thermal power applications. Energy 2018, 149, 473-484. [CrossRef]

7. André, L.; Abanades, S.; Flamant, G. Screening of thermochemical systems based on solid-gas reversible reactions for high temperature solar thermal energy storage. Renew. Sustain. Energy Rev. 2016, 64, 703-715. [CrossRef] 
8. Fujii, I.; Tsuchiya, K.; Higano, M.; Yamada, J. Studies of an energy storage system by use of the reversible chemical reaction: $\mathrm{CaO}+\mathrm{H}_{2} \mathrm{O} \rightleftharpoons \mathrm{Ca}(\mathrm{OH})_{2}$. Sol. Energy 1985, 34, 367-377. [CrossRef]

9. Pardo, P.; Anxionnaz-Minvielle, Z.; Rougé, S.; Cognet, P.; Cabassud, M. Ca(OH) $2 /$ CaO reversible reaction in a fluidized bed reactor for thermochemical heat storage. Sol. Energy 2014, 107, 605-616. [CrossRef]

10. Linder, M.; Roßkopf, C.; Schmidt, M.; Wörner, A. Thermochemical energy storage in kW-scale based on $\mathrm{CaO} / \mathrm{Ca}(\mathrm{OH})_{2}$. Energy Procedia 2013, 49, 888-897. [CrossRef]

11. Dai, L.; Long, X.F.; Lou, B.; Wu, J. Thermal cycling stability of thermochemical energy storage system $\mathrm{Ca}(\mathrm{OH})_{2} / \mathrm{CaO}$. Appl. Therm. Eng. 2018, 133, 261-268. [CrossRef]

12. Criado, Y.A.; Huille, A.; Rougé, S.; Abanades, J.C. Experimental investigation and model validation of a $\mathrm{CaO} / \mathrm{Ca}(\mathrm{OH})_{2}$ fluidized bed reactor for thermochemical energy storage applications. Chem. Eng. J. 2017, 313, 1194-1205. [CrossRef]

13. Yan, J.; Zhao, C.Y. First-principle study of $\mathrm{CaO} / \mathrm{Ca}(\mathrm{OH})_{2}$ thermochemical energy storage system by $\mathrm{Li}$ or Mg cation doping. Chem. Eng. Sci. 2014, 117, 293-300. [CrossRef]

14. Criado, Y.A.; Alonso, M.; Abanades, J.C. Enhancement of a $\mathrm{CaO} / \mathrm{Ca}(\mathrm{OH})_{2}$ based material for thermochemical energy storage. Sol. Energy 2016, 135, 800-809. [CrossRef]

15. Ortiz, C.; Romano, M.C.; Valverde, J.M.; Binotti, M.; Chacartegui, R. Process integration of Calcium-Looping thermochemical energy storage system in concentrating solar power plants. Energy 2018, 155, 535-551. [CrossRef]

16. Chen, X.; Jin, X.; Liu, Z.; Ling, X.; Wang, Y. Experimental investigation on the $\mathrm{CaO} / \mathrm{CaCO}_{3}$ thermochemical energy storage with $\mathrm{SiO}_{2}$ doping. Energy 2018, 155, 128-138. [CrossRef]

17. Benitez-Guerrero, M.; Valverde, J.M.; Sanchez-Jimenez, P.E.; Perejon, A.; Perez-Maqueda, L.A. Multicycle activity of natural $\mathrm{CaCO}_{3}$ minerals for thermochemical energy storage in Concentrated Solar Power plants. Sol. Energy 2017, 153, 188-199. [CrossRef]

18. André, L.; Abanades, S. Evaluation and performances comparison of calcium, strontium and barium carbonates during calcination/carbonation reactions for solar thermochemical energy storage. J. Energy Storage 2017, 13, 193-205. [CrossRef]

19. Wu, S.; Zhou, C.; Doroodchi, E.; Nellore, R.; Moghtaderi, B. A review on high-temperature thermochemical energy storage based on metal oxides redox cycle. Energy Convers. Manag. 2018, 168, 421-453. [CrossRef]

20. Bulfin, B.; Vieten, J.; Agrafiotis, C.; Roeb, M.; Sattler, C. Applications and limitations of two step metal oxide thermochemical redox cycles; A review. J. Mater. Chem. A 2017, 5, 18951-18966. [CrossRef]

21. Alonso, E.; Pérez-Rábago, C.; Licurgo, J.; Fuentealba, E.; Estrada, C.A. First experimental studies of solar redox reactions of copper oxides for thermochemical energy storage. Sol. Energy 2015, 115, 297-305. [CrossRef]

22. Haseli, P.; Jafarian, M.; Nathan, G.J. High temperature solar thermochemical process for production of stored energy and oxygen based on $\mathrm{CuO} / \mathrm{Cu}_{2} \mathrm{O}$ redox reactions. Sol. Energy 2017, 153, 1-10. [CrossRef]

23. Hänchen, M.; Stiel, A.; Jovanovic, Z.R.; Steinfeld, A. Thermally driven copper oxide redox cycle for the separation of oxygen from gases. Ind. Eng. Chem. Res. 2012, 51, 7013-7021. [CrossRef]

24. Clayton, C.K.; Whitty, K.J. Measurement and modeling of decomposition kinetics for copper oxide-based chemical looping with oxygen uncoupling. Appl. Energy 2014, 116, 416-423. [CrossRef]

25. Alonso, E.; Pérez-Rábago, C.; Licurgo, J.; Gallo, A.; Fuentealba, E.; Estrada, C.A. Experimental aspects of $\mathrm{CuO}$ reduction in solar-driven reactors: Comparative performance of a rotary kiln and a packed-bed. Renew. Energy 2017, 105, 665-673. [CrossRef]

26. Schrader, A.J.; Muroyama, A.P.; Loutzenhiser, P.G. Solar electricity via an Air Brayton cycle with an integrated two-step thermochemical cycle for heat storage based on $\mathrm{Co}_{3} \mathrm{O}_{4} / \mathrm{CoO}$ redox reactions: Thermodynamic analysis. Sol. Energy 2015, 118, 485-495. [CrossRef]

27. Block, T.; Knoblauch, N.; Schmücker, M. The cobalt-oxide/iron-oxide binary system for use as high temperature thermochemical energy storage material. Thermochim. Acta 2014, 577, 25-32. [CrossRef]

28. Agrafiotis, C.; Roeb, M.; Schmücker, M.; Sattler, C. Exploitation of thermochemical cycles based on solid oxide redox systems for thermochemical storage of solar heat. Part 2: Redox oxide-coated porous ceramic structures as integrated thermochemical reactors/heat exchangers. Sol. Energy 2015, 114, 440-458. [CrossRef]

29. Neises, M.; Tescari, S.; de Oliveira, L.; Roeb, M.; Sattler, C.; Wong, B. Solar-heated rotary kiln for thermochemical energy storage. Sol. Energy 2012, 86, 3040-3048. [CrossRef] 
30. Tescari, S.; Agrafiotis, C.; Breuer, S.; De Oliveira, L.; Neises-Von Puttkamer, M.; Roeb, M.; Sattler, C. Thermochemical solar energy storage via redox oxides: Materials and reactor/heat exchanger concepts. Energy Procedia 2013, 49, 1034-1043. [CrossRef]

31. Singh, A.; Tescari, S.; Lantin, G.; Agrafiotis, C.; Roeb, M.; Sattler, C. Solar thermochemical heat storage via the $\mathrm{Co}_{3} \mathrm{O}_{4} / \mathrm{CoO}$ looping cycle: Storage reactor modelling and experimental validation. Sol. Energy 2017, 144, 453-465. [CrossRef]

32. Karagiannakis, G.; Pagkoura, C.; Halevas, E.; Baltzopoulou, P.; Konstandopoulos, A.G. Cobalt/cobaltous oxide based honeycombs for thermochemical heat storage in future concentrated solar power installations: Multi-cyclic assessment and semi-quantitative heat effects estimations. Sol. Energy 2016, 133, $394-407$. [CrossRef]

33. Pagkoura, C.; Karagiannakis, G.; Zygogianni, A.; Lorentzou, S.; Kostoglou, M.; Konstandopoulos, A.G.; Rattenburry, M.; Woodhead, J.W. Cobalt oxide based structured bodies as redox thermochemical heat storage medium for future CSP plants. Sol. Energy 2014, 108, 146-163. [CrossRef]

34. André, L.; Abanades, S. Investigation of metal oxides, mixed oxides, perovskites and alkaline earth carbonates/hydroxides as suitable candidate materials for high-temperature thermochemical energy storage using reversible solid-gas reactions. Mater. Today Energy 2018, 10, 48-61. [CrossRef]

35. André, L.; Abanades, S.; Cassayre, L. High-temperature thermochemical energy storage based on redox reactions using Co-Fe and Mn-Fe mixed metal oxides. J. Solid State Chem. 2017, 253, 6-14. [CrossRef]

36. André, L.; Abanades, S.; Cassayre, L. Experimental Investigation of $\mathrm{Co}-\mathrm{Cu}, \mathrm{Mn}-\mathrm{Co}$, and Mn-Cu Redox Materials Applied to Solar Thermochemical Energy Storage. ACS Appl. Energy Mater. 2018, 1, 3385-3395. [CrossRef]

37. Carrillo, A.J.; Serrano, D.P.; Pizarro, P.; Coronado, J.M. Improving the Thermochemical Energy Storage Performance of the $\mathrm{Mn}_{2} \mathrm{O}_{3} / \mathrm{Mn}_{3} \mathrm{O}_{4}$ Redox Couple by the Incorporation of Iron. ChemSusChem 2015, 8, 1947-1954. [CrossRef] [PubMed]

38. Karagiannakis, G.; Pagkoura, C.; Zygogianni, A.; Lorentzou, S.; Konstandopoulos, A.G. Monolithic ceramic redox materials for thermochemical heat storage applications in CSP plants. Energy Procedia 2013, 49, 820-829. [CrossRef]

39. Carrillo, A.J.; Serrano, D.P.; Pizarro, P.; Coronado, J.M. Thermochemical heat storage based on the $\mathrm{Mn}_{2} \mathrm{O}_{3} / \mathrm{Mn}_{3} \mathrm{O}_{4}$ redox couple: Influence of the initial particle size on the morphological evolution. J. Mater. Chem. A 2014, 2, 19435-19443. [CrossRef]

40. Gillot, B.; El Guendouzi, M.; Laarj, M. Particle size effects on the oxidation-reduction behavior of $\mathrm{Mn}_{3} \mathrm{O}_{4}$ hausmannite. Mater. Chem. Phys. 2001, 70, 54-60. [CrossRef]

41. Block, T.; Schmücker, M. Metal oxides for thermochemical energy storage: A comparison of several metal oxide systems. Sol. Energy 2016, 126, 195-207. [CrossRef]

42. Monazam, E.R.; Breault, R.W.; Siriwardane, R. Kinetics of magnetite $\left(\mathrm{Fe}_{3} \mathrm{O}_{4}\right)$ oxidation to hematite $\left(\mathrm{Fe}_{2} \mathrm{O}_{3}\right)$ in air for chemical looping combustion. Ind. Eng. Chem. Res. 2014, 53, 13320-13328. [CrossRef]

43. Kozuka, H. Handbook of Sol-Gel Science and Technology; Volume 1: Sol-gel Processing; Sakka, S., Ed.; Springer Science \& Business Media: Berlin, Germany, 2005; 680 p.

44. Carrillo, A.J.; Serrano, D.P.; Pizarro, P.; Coronado, J.M. Understanding Redox Kinetics of Iron-Doped Manganese Oxides for High Temperature Thermochemical Energy Storage. J. Phys. Chem. C 2016, 120, 27800-27812. [CrossRef]

45. Carrillo, A.J.; Moya, J.; Bayón, A.; Jana, P.; De La Peña O’Shea, V.A.; Romero, M.; Gonzalez-Aguilar, J.; Serrano, D.P.; Pizarro, P.; Coronado, J.M. Thermochemical energy storage at high temperature via redox cycles of Mn and Co oxides: Pure oxides versus mixed ones. Sol. Energy Mater. Sol. Cells 2014, 123, 47-57. [CrossRef]

46. Motuzas, J.; Diniz Da Costa, J.C. Copper aided exchange in high performance oxygen production by CuCo binary oxides for clean energy delivery. J. Mater. Chem. A 2015, 3, 17344-17350. [CrossRef]

47. Kang, Y.B.; Jung, I.H. Thermodynamic modeling of oxide phases in the Fe-Mn-O system. J. Phys. Chem. Solids 2016, 98, 237-246. [CrossRef]

48. Adánez-Rubio, I.; Izquierdo, M.T.; Abad, A.; Gayán, P.; de Diego, L.F.; Adánez, J. Spray granulated Cu-Mn oxygen carrier for chemical looping with oxygen uncoupling (CLOU) process. Int. J. Greenh. Gas Control 2017, 65, 76-85. [CrossRef] 
49. Golikov, Y.V.; Tubin, S.Y.; Barkhatov, V.P.; Balakirev, V.F. Phase Diagrams of the Co-Mn-O System in Air. J. Phys. Chem. Solids 1985, 46, 539-544. [CrossRef]

50. Driessens, F.C.M.; Rieck, G.D. Phase Equilibria in the System Cu-Mn-O. Z. Anorg. Allg. Chem. 1967, 351, 48-62. [CrossRef]

51. Wei, P.; Bieringer, M.; Cranswck, L.M.D.; Petric, A. In-situ High Temperature X-ray and Neutron Diffraction of Cu-Mn Oxide Phases. J. Mater. Sci. 2010, 45, 1056-1064. [CrossRef]

52. Shishin, D.; Hidayat, T.; Jak, E.; Decterov, S.A. Critical assessment and thermodynamic modeling of the $\mathrm{Cu}-\mathrm{Fe}-\mathrm{O}$ system. Calphad 2013, 41, 160-179. [CrossRef]

53. Jacob, K.T.; Fitzner, K.; Alcock, C.B. Activities in the spinel solid solution, phase equilibria and thermodynamic properties of ternary phases in the system Cu-Fe-O. Met. Trans. B 1977, 8, 451-460. [CrossRef]

54. Zhang, W.-W.; Chen, M. Thermodynamic Modeling of the Co-Fe-O System. Calphad 2013, 41, 76-88. [CrossRef]

55. Jung, I.-H.; Decterov, S.A.; Pelton, A.D.; Kim, H.-M.; Kang, Y.-B. Thermodynamic Evaluation and Modeling of the Fe-Co-O System. Acta Mater. 2004, 52, 507-519. [CrossRef]

56. Zabdyr, L.A.; Fabrichnaya, O.B. Phase Equilibria in the Cobalt Oxide-Copper Oxide System. J. Phase Equilib. 2002, 23, 149-155. [CrossRef]

57. Crum, J.V.; Riley, B.J.; Vienna, J.D. Binary Phase Diagram of the Manganese Oxide-Iron Oxide System. J. Am. Ceram. Soc. 2009, 92, 2378-2384. [CrossRef]

58. Kjellqvist, L.; Selleby, M. Thermodynamic assessment of the Cr-Mn-O system. J. Alloys Coump. 2010, 507, 84-92. [CrossRef]

59. Bale, C.W.; Bélisle, E.; Chartrand, P.; Decterov, S.A.; Eriksson, G.; Gheribi, A.E.; Hack, K.; Jung, I.H.; Kang, Y.B.; Melançon, J.; et al. FactSage Thermochemical Software and Databases, 2010-2016. Calphad 2016, 54, 35-53. [CrossRef]

60. Carrillo, A.J.; Serrano, D.P.; Pizarro, P.; Coronado, J.M. Manganese oxide-based thermochemical energy storage: Modulating temperatures of redox cycles by Fe-Cu co-doping. J. Energy Storage 2016, 5, 169-176. [CrossRef]

61. Pashkova, E.V.; Novosadvoa, E.B.; Chalyi, V.P.; Antishko, A.N. Phase Diagram of the Manganese, Iron, and Cobalt oxides. Ukr. Chem. J. 1987, 53, 26-29.

62. Lalanne, M.; Barnabé, A.; Mathieu, F.; Tailhades, P. Synthesis and Thermostructural Studies of a $\mathrm{CuFe}_{1-x} \mathrm{Cr}_{\mathrm{x}} \mathrm{O}_{2}$ Delafossite Solid Solution with $0 \leq \mathrm{x} \leq 1$. Inorg. Chem. 2009, 48, 6065-6071. [CrossRef] [PubMed] 